Lola Annabel Kass

\title{
PICTURING MELANCHOLIA IN ESTONIAN DECADENT ART
}

\section{INTRODUCTION}

This study ${ }^{1}$ focuses on the Estonian decadent art of the early twentieth century that manifests the topicality of melancholia, meaning a mood (great sadness, sorrow, gloom, despondency) and an illness (synonymous with a depression). ${ }^{2}$ More specifically, I examine the theme of melancholia: visual art that depicts sadness, low spirits, malaise and suicidal behaviour. The article seeks to answer how

DOI: https://doi.org/10.12697/BJAH.2020.19.01

1 This article is part of my doctoral thesis. I partly rely on my earlier writing on decadent art: "Eesti dekadentlik kunst. Teemad ja kujundid ning baudelaire'lik tundeilm", Kurja lillede lapsed. Eesti dekadentlik kunst = Children of the Flowers of Evil: Estonian Decadent Art, ed. by Mirjam Hinrikus, Lola Annabel Kass, Liis Pählapuu (Tallinn: Eesti Kunstimuuseum; Eesti Teaduste Akadeemia Underi ja Tuglase Kirjanduskeskus, 2017), 56-113, 225-238; Lola Annabel Kass, "Värvikas raskemeelsus Friedebert Tuglase ja Konrad Mägi looduspildis", Mäng ja melanhoolia. Friedebert Tuglase "Felix Ormusson", ed. by Mirjam Hinrikus, Jaan Undusk (Tallinn: Eesti Teaduste Akadeemia Underi ja Tuglase Kirjnaduskeskus), [forthcoming].

2 In Western medical and cultural tradition melancholia/melancholy has been defined as characteristic disposition, mood and illness. As an illness melancholia had various symptoms such as long-lasting sadness, morose, fear, irritability, sleeplessness, hallucinations and increase in creativity. In the late $19^{\text {th }}$ century its meaning and symptoms were narrowed and it became synonymous with depression. However, the term was still used in a broader meaning: illness and mood (that didn't require treatment). See László F. Földényi, Melancholy, trnsl. by Tim Wilkinson (New Haven, London: Yale University Press, [1984] 2016); Jennifer Radden books The Nature of Melancholy: From Aristotle to Kristeva (Oxford: Oxford University Press, 2000) and Moody Minds Distempered, Essayd on Melancholy and Depression (Oxford: Oxford University Press, 2009). 
artists imagined and visualised melancholia. What were the most common techniques used to depict it in Estonian art? Why were portrayal of feelings of malaise and low spirits so widespread from the beginning of the $20^{\text {th }}$ century? I argue that a tendency among Estonian artists to depict melancholia was triggered by the popularity of decadence, itself the influence of foreign and local decadent works of art and literature. However, other important stimuli were the widely circulated degeneration theories (Bénédict Morel, Max Nordau, et al.), and in connection with these theories the increasing interest in psyche-related problems, as frequently discussed by doctors, the intelligentsia and the press. Therefore, in the first section of this article I observe the ideas about psychological problems that had gained ground in Estonian medical circles and society at large during the early $20^{\text {th }}$ century. Since melancholia is predominantly expressed in the visual arts through the metaphor of the physical, I have taken heed of the influence of various written descriptions (medical and social theories, literature, poetry) of mental health issues and melancholia on perceptions of the body and psychological problems. The aim is to understand how melancholia was thought about, and if or in what way these conceptions were visualised in decadent art, as well as what kind of physical symptoms, images and expressions were associated with this condition? As a dark and sombre mood was often symbolised with colours and natural images in art and literature, I have studied the relative importance of various European artworks, and literary and theoretical texts. More specifically, work that deals with the symbolic meaning of natural elements and colour, colour psychology, and the relationship between climate and human temperament. Thus, in the form of intertexts to social processes I also analyse written and visual texts that shaped the ways melancholia was understood and depicted. In the section devoted to analysis of decadent pictures I highlight, by drawing on a close reading of the methodology of Mieke Bal ${ }^{3}$, the major intertextual figures and compositional techniques that were used to communicate melancholia through art.

3 Mieke Bal, "Lugeda kunsti”, Kunstiteaduslikke Uurimusi, 20, 1-2 (2011), 213-228. The original title is "Reading Art", transl. from publication: Mieke Bal Reader (Chicago, London: University of Chicago Press, 2006). First publication: Generations and Geographies in the Visual Arts: Feminist Readings (London: Routledge, 1996), 25-41. 


\section{THE CHARACTERISTICS OF DECADENT ART}

Decadence or decadent art, which emerged in Western countries in the late- $19^{\text {th }}$ century, expresses a strong interest in the human psyche and in intense feelings or extreme emotional states such as ecstasy, anger, anxiety and melancholia. This interest comprises depiction of different mental conditions and feeling and elicits emotion from the viewer. ${ }^{4}$ A dominant feature of decadent work is the tendency to portray subject matter that is considered repulsive, vicious and deviant both by the conservative bourgeoisie and Christian belief. ${ }^{5}$ Mental illnesses and deviation from 'normal' perception, thought or behaviour are prevalent topics in the decadent visual arts and literature. There are, for example, portraits of people who have sad and discontented or even tortured expressions, in which the emphasis is not on a resemblance to the person portrayed, but rather on conveying a sick and traumatised psyche or a morbid inner world. ${ }^{6}$ Researchers into decadent art Otto M. Urban and Michelle Facos define decadence as a cultural phenomenon, a pessimistic frame of mind. They define decadent art by its content rather than its form, and emphasise different manifestations of decay and degeneration as central characteristics of decadent artwork. ${ }^{7}$ Decadent works deal with the so-called dark side of humanity - illnesses and emotional pain, nightmares, prostitution, corruption, substance addiction, violence and death. ${ }^{8}$ Decadent works are characterised by a metaphorical or symbolic mode of expression, although at the same time the subject matter is manifested through diverse techniques and styles. Urban, for example, chose the charcoal drawing Expressive Head (Expresivní hlava, ca. 1900) by Czech artist Jaroslav Panuška as

4 Emotional intensity and an interest in the psyche are also typical of the period's decadent literature. Nordic Literature of Decadence, ed. by Pirjo Lyytikäinen, Riikka Rossi, Viola ParenteČapková, Mirjam Hinrikus (New York, London: Routledge, 2019).

5 Read about decadence Otto M. Urban, In Morbid Colours: Art and the Idea of Decadence in the Bohemian Lands 1800-1914 (Praha: Arbor Vitae, 2006); Michelle Facos, Symbolist Art in Context (Berkeley, Los Angeles, London: University of California Press, 2009), 65-89.

6 Urban, In Morbid Colours: Art and the Idea of Decadence in the Bohemian Lands 18001914, 81-83, 130-131, 151, 327.

7 Ibidem, 11-13, etc.; Facos, Symbolist Art in Context, 65-89. See also note 10 below.

8 Urban, ibidem; Ian Willoughby, "Exhibition focuses on 'decadence' in art of late 19 , early $20^{\text {th }}$ centuries", Radio Prague International, 15.11.2006, https://english.radio.cz/exhibitionfocuses-decadence-art-late-19th-early-20th-centuries-8613761 [accessed on 02.08.2020]. 
the cover of his book Decadence in Morbid Colours: Art and the Idea of Decadence in the Bohemian Lands 1880-1914 (2006). The drawing visualises fear or anxiety in a symbolic manner, but the technique use is expressionistic. By putting such an image on the cover Urban emphasises that decadent art is characterised by the aforementioned ways of perceiving and speaking or visualising. In Estonia, I am the first art historian to study decadent art using such an approach.

However, the term decadence has been discredited for a long time and has not really been expounded in Estonia. Decadent work was often categorised in art historical writing under 'expressionism'. This has happened because decadence and expressionism explore the world of imagination and share a pessimistic attitude towards their era and critical interest in ever-modernising environment. They both point their focus of interest at the human psyche and 'transgressive' phenomena, i.e. at breaking up deep-rooted norms and beliefs. It is for this reason that the umbrella term fin-de-siècle has been applied to analyses outside Estonia. ${ }^{10}$ Yet, in Estonian art history and literary studies, the term 'decadence' had a negative connotation for various reasons and has therefore generally been avoided. At the beginning of the $20^{\text {th }}$ century, when the first Estonian decadent works were created and the term decadence was introduced by modernist writers, ${ }^{11}$ conservatives began to associate 'decadence' with the degeneration

9 See, for example, Ene Lamp, Ekspressionism: Ekspressionism Eesti kujutavas kunstis (Tallinn: Eesti Kunstiakadeemia, 2004). The book includes artworks that could be defined as decadent, and the author Ene Lamp discusses issues that have been related both to decadence and expressionism.

10 See publications: The Fin-de-Siècle World, ed. by Michael Saler (New York, London: Routledge, 2015); Nathan J. Timpano, Constructing the Viennese Modern Body: Art, Hysteria, and the Puppet (New York: Routledge, 2017). The synonym for decadence is fin-de-siècle, which denotes ways of speaking and perceiving that began to dominate at the turn of the $19^{\text {th }}-20^{\text {th }}$ centuries. It was based on the widespread notion that modern Western civilisation was degrading, and the outbreak of WWI was regarded as the peak and proof of that. On the other hand, decadence reveals a positive attitude towards degradation and decay, accompanied with the belief that an era of degeneration was also an age of transition: stagnant perceptions and manners of behaviour, etc., would be replaced by new ones. Matthew Potolsky, "Introduction", New Literary History. Forms and/of Decadence, 35 (4) (2004), v-x; Mirjam Hinrikus, Lola Annabel Kass, "Summary. Decadence in Estonian Culture in The Early $20^{\text {th }}$ Century", Kurja lillede lapsed. Eesti dekadentlik kunst $=$ Children of the Flowers of Evil. Estonian Decadent Art, ed. by Mirjam Hinrikus, Lola Annabel Kass, Liis Pählapuu (Tallinn: Eesti Kunstimuuseum; Eesti Teaduste Akadeemia Underi ja Tuglase Kirjanduskeskus, 2017), 225.

11 The first text in Estonia which both introduced Charles Baudelaire's decadent works and defined the word decadence was an article published in 1905 by Johannes Aavik, an Estonian writer and philologist. Johannes Aavik, "Charles Baudelaire ja dekadentismus", Noor-Eesti I (Tartu: Kirjanduse Sõprade kirjastus, 1905), 194-200. 
of art and literature (as in other European countries). ${ }^{12}$ There was a general tendency to condemn any kind of modern art and literature by nationally minded conservatives. This was a period of turbulent creativity of Estonian-minded Estonian-language indigenous culture, including attempts by the young intelligentsia to modernise local culture using the model of Western Europe that ran in parallel to the period of national awakening, inaugurated in the second half of the $19^{\mathrm{TH}}$ century. The purpose of the national awakening movement was to identify the Estonian national idiosyncrasy and be free of external influence, German and Russian in particular. The Estonian cultural space with its own art institutions and practices was only beginning to emerge, and at this time non-realistic art was something unfathomable for the majority of the population. ${ }^{13}$ Later, during the Soviet period, it was considered inappropriate to write about decadence because of the associated negative connotations. Today, decadence has gained most interest within literary studies. ${ }^{14}$

\section{ON THE TOPICALITY OF MENTAL HEALTH ISSUES IN ESTONIAN MEDICINE AND SOCIETY IN THE EARLY $20^{\mathrm{TH}}$ CENTURY}

At the beginning of $20^{\text {th }}$ century, increasing attention was paid in Estonia to moods and mental disorders, i.e. to various psychological problems regarded as illnesses. This interest was brought about by the development of psychiatry ${ }^{15}$ as a separate field of medicine in the $19^{\text {th }}$ century and by the emergence of nationally minded Estonian

12 Johannes Aavik, "Noor-Eesti arvustus", Noor-Eesti: kirjanduse, kunsti ja teaduse ajakiri, 2 (1910/1911), 115-119; Mirjam Hinrikus, "Ambivalentsest dekadentsist ja selle sümptomitest Paul Bourget' ja Friederich Nietzsche tekstides ning Fridebert Tuglase romaanis "Felix Ormusson",, Autogenees ja ülekanne: moodsa kultuuri kujunemine Eestis, ed. by Rein Undusk (Tallinn: Underi ja Tuglase Kirjanduskeskus, 2014), 201-203; Kaia Sisask, Noor-Eesti ja prantsuse vaim (Tallinn: TLÜ Kirjastus, 2018), 58-60.

13 The first Estonian art exhibition was held in 1906. The first institutions in Estonia that enabled art education where artist's Ants Laikmaa and Kristjan Raud studio schools. These were opened, accordingly, in 1903 and in 1904.

14 Most prominent researchers are Mirjam Hinrikus, Merlin Kirikal and Kaia Sisask. See publications online at https:/www.etis.ee/CV/Mirjam_Hinrikus/est?lang=ENG\&tabId=CV ENG; https://www.etis.ee/CV/Merlin_Kirikal001/eng?lang=ENG; https://www.etis.ee/CV/ Kaia_Sisask/eng?lang=ENG [accessed on 10.07.2020].

15 In Estonia (Russian Empire) the first associations and medical institutions that took care of mentally ill people were founded in the $19^{\text {th }}$ century. The department of psychiatry was founded at Tartu University in 1880 . 
doctors. A more direct influence in Europe, including Estonia, came from discussions about degeneration, breed, the surfacing ideas of eugenics, study of heredity. The theory of evolution inspired studies into the regression of the individual and of society: "all manner of physical, psychological and moral weakening." 16 These tendencies were further encouraged by a rise in the national self-awareness of Estonians and incorporated a wish to create an indigenous culture and gain independence. The intelligentsia and doctors began to deal with the issue of preserving the Estonian breed as well as improving the breed qualities and decelerating the on-going (mental) degeneration. ${ }^{17}$ In the early $20^{\text {th }}$ century, there was a widespread understanding that the Estonian breed was of poor quality and that Estonians were predisposed to developing various mental health issues. From the second half of the 1920s the media began increasingly to reflect on the conviction that this period of modernisation and rapid changes to the social environment was generating stressed individuals. For example, a newspaper article from 1933 suggests that "civilisation with a highly developed culture and a pulsating pace of life has ruined the nerves of modern mankind."18 Among other factors, an increase in mental illnesses and the frequency of suicide gave cause to speak about 'nervousness': "Almost everywhere we come across people with wrecked nerves who have mood swings: at one moment they are happy, at the next gloomy, complaining of headaches, lack of appetite, impotency, etc. We constantly read in newspapers about neurasthenics committing suicide and behaving strangely." 19

16 Päivi Molarius, "Will the Human Race Degenerate? The individual, the family and the fearsome spectre of degeneracy in Finnish literature of the late $19^{\text {th }}$ and early $20^{\text {th }}$ century", Changing Scenes: Encounters between European and Finnish Fin de Siécle, ed. by Pirjo Lyytikäinen (Helsinki: Finnish Literature Society, 2003), 121.

17 Ken Kalling, "The Application of Eugenics in Estonia 1918-1940”, Baltic Eugenics: BioPolitics, Race and Nation in Interwar Estonia, Latvia and Lithuania 1918-1940, ed. by Björn M. Felder, Paul J. Weindling (Amsterdam: Rodopi, 2013), 49-52; Ken Kalling, "Galerii omadest ja võõrastest: Neurasthenia estonica ja need teised diagnoosid", Novaator, 04.12.2015, https:// novaator.err.ee/258152/galerii-omadest-ja-voorastest-neurasthenia-estonica-ja-need-teiseddiagnoosid [accessed on 06.07.2020].

18 "Meie oleme närvilikud! Neurasteenia - moodsa aja pahe. Mida vajame ravimiseks?", Nool, 04.03.1933.

19 Jaan Speek, "Kaks iseäralist rahvaste liikumise põhjust. I", Sakala, 05.05.1919; Aleksander Ibrus, "Mõnda enesetappest" - Neljas Arstide Päev 1925, Eesti Arst, 12 (1926), 37; "Olla või mitte olla. "Postimehele" kirjutanud dr. W. E. Peters, M.A.", Postimees, 23.12.1928; citation is from the article "Prof. Puusepa kõne praeguse aja närvihaigusist", Kaja, 12.02.1931. 
Physician Peeter Hellat was a founder of the Estonian society of doctors (the North Baltic Doctors Society, established 1912) and an authority in Estonian medical circles. He suggested there was an illness called hysteria estonica - the disease of unfamiliar life spreading among Estonians, manifesting itself as restlessness, boredom, impatience and anxiety. ${ }^{20}$ One could claim that the condition resembled neurasthenia, which manifested itself in melancholic feelings, physical and mental fatigue, irritability and other types of somatic symptom brought about by exhaustion and low levels of resistance to stress. ${ }^{21}$ It is significant that Hellat, writing about hysterica estonica in a letter to the renowned Estonian psychiatrist Juhan Luiga, gave a new name to the illness: neurastenia estonica. ${ }^{22}$ Luiga was studying the frequency of neurasthenia among Estonians, resulting in his Neurasthenia (Närvinõrkus) in 1908. In this book Luiga stated that the frequent occurrence of nightmares in old folk tales ${ }^{23}$ proved that Estonians suffered widely from neurasthenia. Nightmares as expressions of hallucination were, according to Luiga, a symptom of the illness..$^{24}$ Ideas about the bad Estonian breed were not, however, confined to the circle of doctors, they also made their way into public discussion in the press and into works of literature. ${ }^{25}$

20 Peeter Hellat, Tervise õpetus (Peterburi: A. Franzschl; Tartu: K. Mattiesen, 1894), 453; Kalling, "Galerii omadest ja võõrastest: Neurasthenia estonica ja need teised diagnoosid".

21 George Miller Beard, A Practical Treatise on Nervous Exhaustion (Neurasthenia) (New York: W. Wood and Company, 1880), 78, 84, 119; Juhan Luiga, Närvinõrkus (Tallinn: August Busch, 1908), 5-8; Charles E. Rosenberg, "The Place of George M. Beard in Nineteenth-Century Psychiatry", Bulletin of the History of Medicine, 36 (3) (1962), 247-259; Kalling, "Galerii omadest ja võorrastest: Neurasthenia estonica ja need teised diagnoosid".

22 Luiga, Närvinõrkus, 5; Kalling, "Galerii omadest ja võõrastest: Neurasthenia estonica ja need teised diagnoosid".

23 Luiga was interested in Estonian culture and history, he also wrote about art and Estonian prehistoric religion.

24 Luiga, Närvinõrkus, 6; Juhan Luiga, "Meelehaigus rahvaluules", Mäss ja meelehaigus, ed. by Hando Runnel (Tartu: Ilmamaa, 1995 [1912]), 106-131.

25 Leena Kurvet-Käosaar, ““The Vitality of Primeval Peasant Blood”: The Hereditary Potential of Estonians in the Work of Aino Kallas", Aino Kallas: Negotiations with Modernity, ed. by Lea Rojola, Leena Kurvet-Käosaar (Helsinki: Finnish Literature Society, 2011), 96-100. Luiga claimed in contrast to the widespread belief in the frequency of mental issues among Estonians that the latter did not suffer from them more frequently than other European nations. Luiga, "Enesetapmine Liivimaal", Postimees, 29.08.1903; Karl Toomingas, "Dr. med. Juhan Luiga psühhiaatrina”, Vaimse hügieeni ühing II (Tartu: Eesti Arst, 1938), 8-9. Estonian doctors had a dual approach to mental health issues: on the one hand they tried to repudiate the negative image of Estonians (created by Baltic-Germans and Russians), on the other hand, after having studied mental illnesses spreading among Estonians, concluded that they were nevertheless frequent. Correspondence with Ken Kalling on 21 February 2020. Thus, another impetus for studying the mental health of Estonians was the colonialist, degrading look of foreign powers on Estonians. See also Ulrike Plath, Esten und Deutsche in den baltischen Provinzen Russlands. Fremdheitskonstruktionen, Lebenswelten, Kolonialphantasien 1750-1850 (Wiesbaden: Harrassowitz, 2011). 
Neurasthenia was a frequently diagnosed illness both in Europe and the USA from the end of the $19^{\text {th }}$ century and it was believed to be partially caused by the nervousness of the era. Neurasthenia was first described in 1869 by neurologist Georg Miller Beard, who stressed that environmental factors played a role in the development of the illness. ${ }^{26}$ Urbanisation with the accompanying increase in the use of technology and the switch from an agrarian lifestyle to an urban one, as well as a modification of values, were considered to be at the root of the problem. Continuing changes in connection to the fast developing and spreading modern civilisation were regarded as the cause of an overall imbalance on the emotional as well social level, that manifested in different mental health issues (including melancholia and neurasthenia). ${ }^{27}$ Hellat, for example, who used the term 'disease of unfamiliar life', believed that Estonians mental health problems might have been the result of emancipation and modernisation, which had brought about drastic changes in society. ${ }^{28}$

German sociologist Georg Simmel wrote about the effect of urbanisation on the human psyche and behaviour, claiming that big cities constituted a constant stimulus to the nervous system with an overload of information, light and noise along with the endless hustle and bustle. All this leads to the emergence of a mentally exhausted type of person, the "metropolitan type", who tries to protect his or her psyche with a "blasé" mask that stands for a state of being as well as an attitude, characterised by boredom, seclusion, superficiality and make-believe indifference. ${ }^{29}$ The above is manifested visually in the Estonian artist Nikolai Triik's drawing Metropolis (Suurlinn, 1913, Fig. 1) made in Berlin. ${ }^{30}$ Triik seems to be implying that contemporary urban

26 George Miller Beard, "Neurasthenia or nervous exhaustion", Boston Medical and Surgical Journal, 80 (1869), 217-221; Rosenberg, "The Place of George M. Beard in Nineteenth-Century Psychiatry", 245-259.

27 Jonathan Flatley, Affective Mapping. Melancholia and the Politics of Modernism (Cambridge, London: Harvard University Press, 2008), 28-31; Mirjam Hinrikus, "Paul Bourget - dekadentsi teoreetik ja kriitik", Esseid kaasaja psühholoogiast (Tallinn: SA Kultuurileht, 2011), 116; Ken Kalling, Meditsiini ajalugu (Tartu: Tartu Ülikool, peremeditsiini ja rahvatervishoiu instituut, 2017), 170; Riho Paramonov, Eesti ühiskonna moderniseerumine avaliku privaattranspordi (voorimees ja takso) näitel, 1900-1940. Dissertation (Tallinn: Tallinna Ülikool, 2019), 40-41.

28 Hellat, Tervise õpetus, 175, 453-454; Kalling, "The Application of Eugenics in Estonia 1918-1940", 51.

29 Georg Simmel, "The Metropolis and Mental Life", The Urban Sociology Reader, ed. by Jan Lin, Christopher Mele (London, New York: Routledge, 2005), 24-31.

30 Evi Pihlak, Nikolai Triik 1884-1940 (Tallinn: Kunst, 1969), 104-105. 


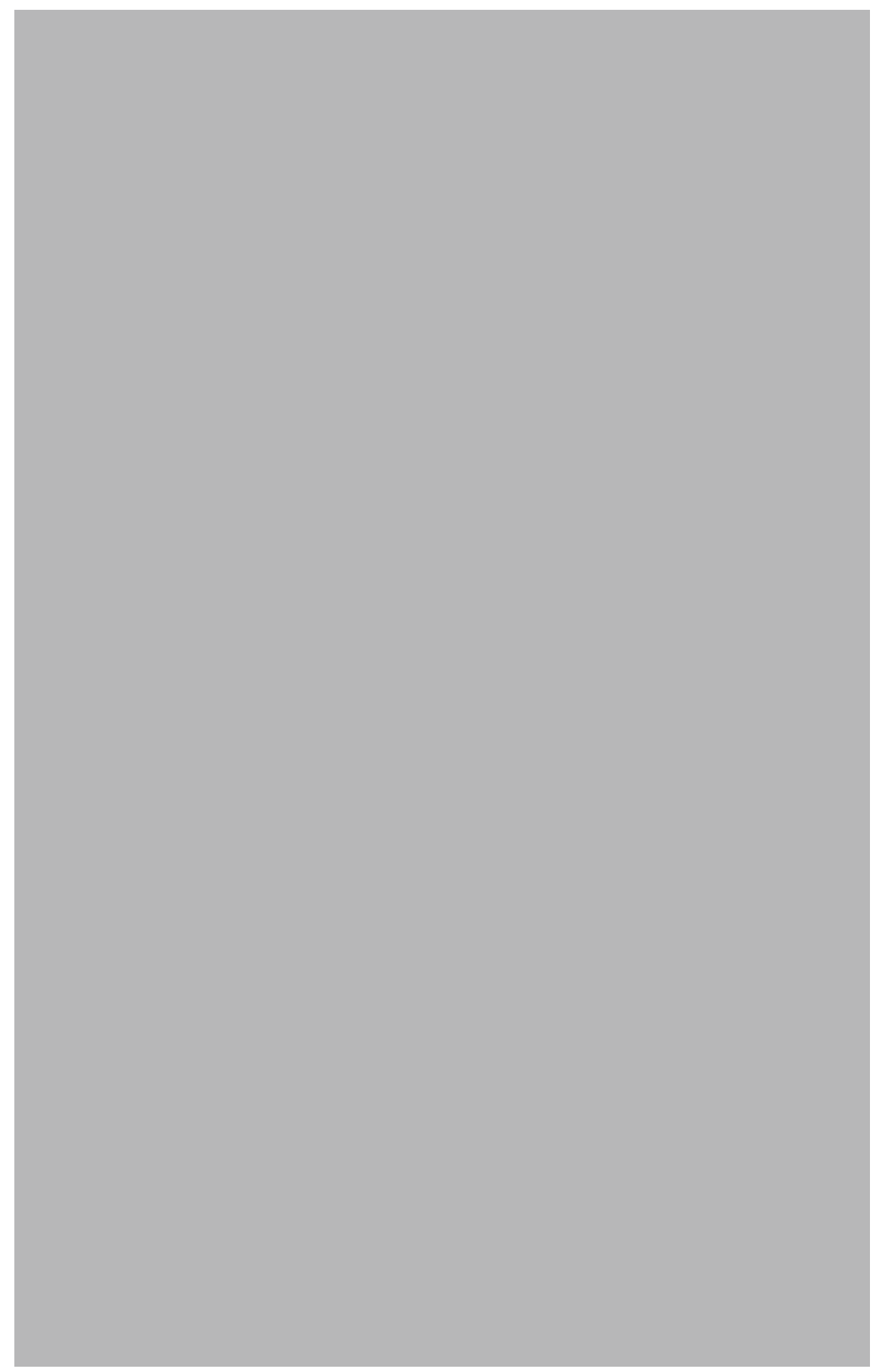

FIG. 1. NIKOLAI TRIIK, METROPOLIS, INDIAN INK, SEPIA, GRAPHITE, GOUACHE ON PAPER (1913). 59.5 × 40.8 CM. TARTU ART MUSEUM. PHOTO: TÕNU TAMM. 
environment causes different psyche-related problems. In the left corner of the picture are people with a typically blasé look, depicted with black blotches marking their eyes, spending their time in the café. Among them is one lady with a white coffee mug, who seems to be sad not blasé, as she is drawn in a melancholia pose with inclined head resting on her hands. ${ }^{31}$ The worn-out and unhappy people are contrasted by the vibrant and noisy view of a metropolis on the right with its dashing modern vehicles, electrical lights and a sky overcast by exhaust fumes. Hence, it was the deviation of the urban living environment from stable and perceivably calm rural life that was regarded as the root of the issue. Noise generated by industrialisation or technologies was not present in the countryside or in the former agrarian living environment, and the air was not polluted by exhaust fumes. Neither were there densely populated settlements or any of that intensity typical of the (modern) urban working environment and social exchange. ${ }^{32}$ It could be claimed that the increased intensity of urban living was one of the main reasons why cities were associated with the nerve-racking pace of life and relaxation was sought in 'timeless' wildernesses or the countryside.

It was also believed that civilisation increased the melancholic mood because more civilised people were more demanding: they were looking for a meaning and purpose in life and chasing ideals, or felt a constant need for pleasure and distraction, and were easily disappointed..$^{33}$ These issues are wittily pointed out by one of the most renowned caricaturists of the period, Vello Agori aka Gori, who depicts a wealthy woman feeling low because she had run out of cocaine (The Life Troubles of the Crème de la Crème, Koorekihi elumure, 1928, Fig. 2) and an artist hanging himself from a sculpture (The Suicide of a Genius, Geeniuse vabasurm, 1928, Fig. 3). ${ }^{34}$ The latter brings to

\section{See note 74.}

32 The change to a more intense life was also associated with the standardisation of time, the transition to 24-hour timing which, in its turn, led to a wide-ranging transformation in society, and also to health problems, according to doctors. Fae Brauer, "Capturing Unconsciousness. The New Psychology, Hypnosis, and the Culture of Hysteria", A Companion to the NineteenthCentury Art, ed. by Michelle Facos (New York: Willey Blackwell, 2019), 243-245.

33 Ludvig Puusepp, Noorus ja eluväärtus: noorsoo enesetapmiste andmetel (Tartu: J. Mällo, 1926), 7-9, 15; Ibrus, "Mõnda enesetappest", 37-38; "Olla või mitte olla. "Postimehele" kirjutanud dr. W. E. Peters, M.A.”, Postimees, 23.12.1928.

34 Caricatures were published in his book Gori, Knock-out: karrikatuurid ja vested (Tallinn: Ringraadio, 1928), 22, 76. 


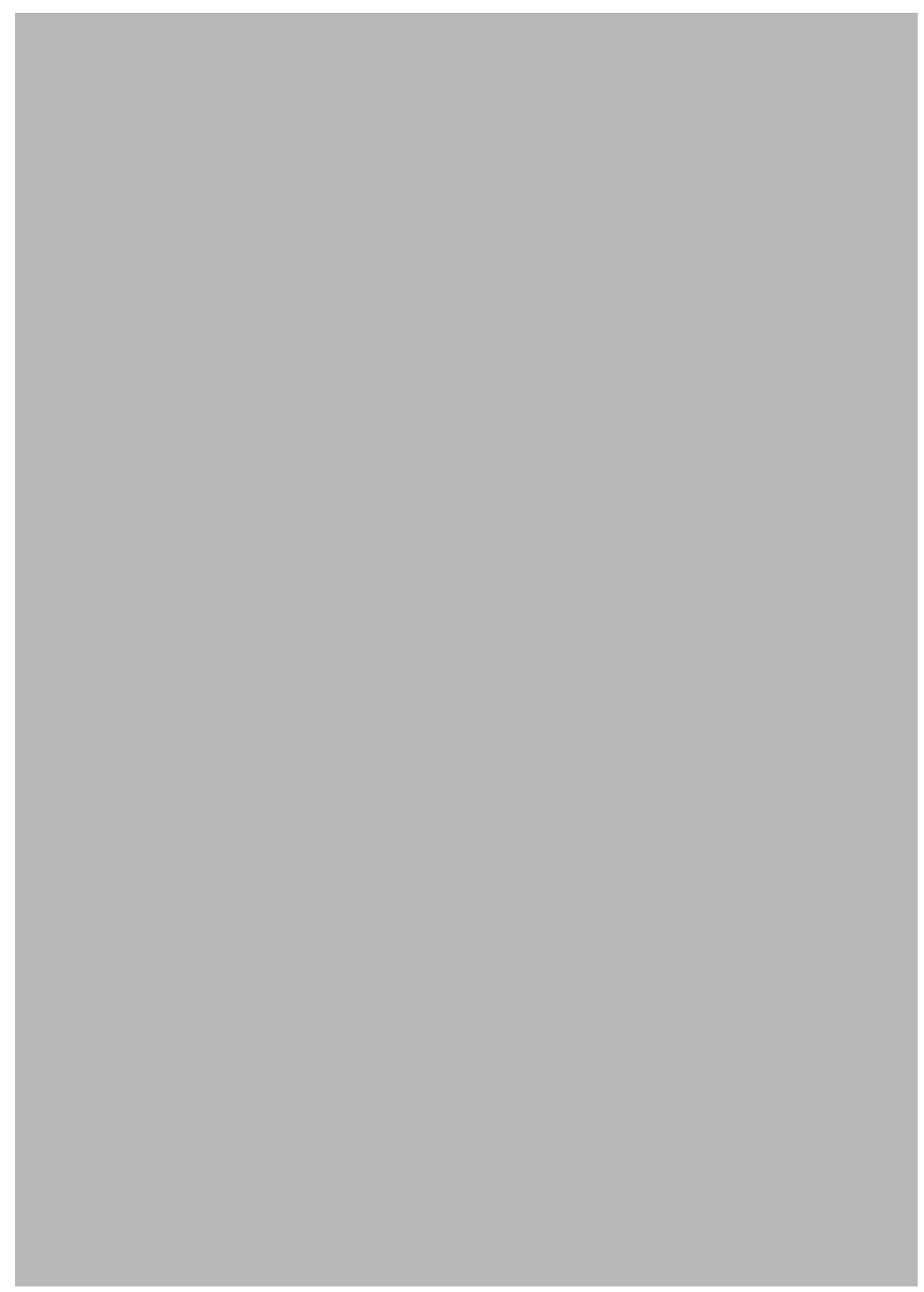

FIG. 2. GORI, THE LIFE TROUBLES OF THE CRÈME DE LA CRÈME: I'VE BEEN WITHOUT A COCAINE FOR ALREADY TWO DAYS AND YET THE POPULACE LIKES TO ARGUE THAT WE HAVE NO WORRIES!, INDIAN INK, GOUACHE ON PAPER (1928). $29.1 \times 20.7$ CM. ART MUSEUM OF ESTONIA. PHOTO: STANISLAV STEPAŠKO. 
FIG. 3. GORI, THE SUICIDE OF A GENIUS, INDIAN INK, PENCIL, WATERCOLOUR ON PAPER (1928). LOCATION UNKNOWN. SOURCE: GORI, KNOCK-OUT: KARIKATUURID JA VESTED (TALLINN: RINGRAADIO, 1928). 
mind the writings of Paul Bourget, a well-known $19^{\text {th }}$-century author and essayist, who claimed that low spirits were caused by being in conflict with the reality of life. In short, when a person has wishes and aims, but reality does not facilitate them, the person becomes unhappy. Intellectuals (the creative intelligentsia) were particularly prone to this because of their subtle emotionality and high ideals. ${ }^{35}$ Luiga claimed that creative people were inevitably unbalanced and "deviant", which meant that they sensed and interpreted life phenomena in idiosyncratic ways; at the same time, he believed it to be necessary for the creation of art. ${ }^{36}$ This was a widespread belief which found further justification in the turn-of-the-century genius theory of criminal anthropologist Cesare Lombroso, according to whom the talents of geniuses developed at the expense of other characteristics. Hence, mental health issues (including melancholia) and brilliance were regarded as interlinked in a causal relationship. ${ }^{37}$

When talking about the topicality of mental health issues, doctors believed and journalists wrote that there were problems with melancholia and even suicidal thoughts in early-20 $0^{\text {th }}$-century Estonia. Persistent low spirits was defined as illness, either as a complication of another disease such as neurasthenia, or as a physiological and psychological disorder. Suicidal behaviour was generally seen as a sign of illness, although it was noted that sometimes mentally and physically healthy people committed suicide, too. In the latter case, suicidal thoughts and acts were seen as a reaction to life's difficulties and the result of a crushed spirit or even moral weakness. ${ }^{38}$

For example, one of the pioneers of neurosurgery Ludvig Puusepp, who studied the causes of neurasthenia as well as hysteria and

35 Paul Bourget, Esseid kaasaja psühholoogiast, trans. by Heete Sahkai (Tallinn: SA Kultuurileht, 2011 [1883]), 11-14. See: Paul Bourget, “The Example of Baudelaire, transl. Nancy O'Connor", http://cat.middlebury.edu/ nereview/30-2/Bourget.htm [accessed on 08.07.2020].

36 Juhan Luiga, "Juhan Liiv. Mälestused ja märkused I”, Mäss ja meelehaigus, ed. by Hando Runnel (Tartu: Ilmamaa, 1995 [1914]), 506, 505-518; Juhan Luiga, "Haiglaslikud ilmed terves inimhinges”, Vaimse Hügieeni Ühing 2 (Tartu: Eesti Arst, 1938 [1927]), 2.

37 Cesare Lombroso, The Man of Genius, ed. by Havelock Ellis (London: Walter Scott, 1891 [1889]), v-xi.

38 Juhan Luiga, "Ihu ja hinge vahekord", Eesti Kodu, 2 (1908), 42; "Seda ja teist, Perekonnaleht: Päevalehe", Aja ja Koidu hinnata kaasanne, 14.02.1909; "Enesetapmised praegusel ajal. D. Schbankovi järele lühendatult", Tallinna Teataja, 11.05.1910; K. R. P., "Sellest külmast maailmast", Päevaleht, 04.02.1911; “Enesetapmise põhjused”, Tallinna Teataja, 05.03.1912; Ibrus, "Mõnda enesetappest", 37-41; Konstantin Lellep, "Kuritegevus Eestis”, Eesti Arst, 1 (1927), 17; "Kas enesetapmine on patt?", Postimees, 10.12.1929; Martin Morrison, Enesetapmiste vastu (Tallinn: J. Ratasep, 1934). 
suicide, ${ }^{39}$ defined suicide in his book Youth and the Value of Life (Noorus ja eluväärtus, 1926) as a "purely biological phenomenon", a psychological disease, a malfunction and developmental disorder of the organism, or as an "insufficient development of the life instinct". 40 This definition is inspired by Sigmund Freud, ${ }^{41}$ whose book Beyond the Pleasure Principle (Jenseits des Lustprinzips, 1920) paired the terms "death drive" and "life drive". The latter was the will to live or instinct to survive that manifested itself in everything that favoured life, such as procreation and eating. The "death drive", on the other hand, meant a drive to be dead. In other words, everything that could have a destructive effect on the body or on co-existence: aggression against oneself or others, recurring traumatic thoughts, etc. ${ }^{42}$ Freud sated that both drives are innate in all humans. Thus, the death wish is not a manifestation of the disorder of the life drive. However, he disapproved of suicide. According to his theories a suicidal person is someone whose death-drive prevails over his or her life-drive. ${ }^{43}$ And at the same time, Puusepp's way of interpreting psychological problems as biological illnesses is based on $19^{\text {th }}$-century psychiatric theory (advocated mainly by Bénédict Morel) according to which the causes of mental illnesses (including suicidal behaviour) are mainly biological and hereditary. This means that mental illnesses can intensify in the next generations and be further aggravated due to various extracorporeal factors, e.g. alcoholism, promiscuity or infection. ${ }^{44}$ Puusepp also regarded extracorporeal factors as important, such as the inability of a weaker individual to handle traumatic events and live up to norms, which in turn led to a lack of

39 Puusepp held public lectures on hysteria and neurasthenia and gave advice on how to deal with them. "Neurasteenia. Professor Dr. L. Puusepa loeng", Kaja, 23.02.1925; "75 protsenti inimesi on närvihaiged", Päevaleht, 13.01.1930; "Prof. Puusepa kõne praeguse aja närvihaigusist".

40 Ludvig Puusepp, Noorus ja eluväärtus, 6-7, 10, 36, etc.

41 Puusepp, among several other doctors, practiced psychotheraphy. For example, he also gave a public lecture on sexuality and Freud's psychoanalysis at the concert hall of the Estonian National Opera in 1930 - the place selection shows the popularity of psychoanalysis, sexuality and Puusepp. Prof. Dr. med L. Puusepp "Suguelu küsimus", Vaba Maa, 26.10.1930.

42 Sigmund Freud, Beyond the Pleasure Principle, transl. and ed. by James Strachey, intro. by Gregory Zilboorg (New York, London: Norton, 1959 [1920]), xiv-xv, chpt. vi; Ernest Jones, The Life and Work of Sigmund Freud, vol. 3 (New York: Basic Books, 1953), 272-275.

43 George Howe Colt, The Enigma of Suicide (New York: Touchstone, 1991), 195-196.

44 Ibidem, 187-188; Ken Kalling, "Karskustöö sünnitab egueenikaliikumise", Mäetagused, 36 (2007), 62-64, https://www.folklore.ee/tagused/nr36/kalling.pdf [accessed on 06.07.2020]; Kalling, Meditsiini ajalugu, 179-180. 
self-confidence and pessimism. ${ }^{45} \mathrm{He}$ also refers to WWI as one of the major causes of the rise of melancholia. ${ }^{46}$ It is worth noting that in this view point on traumatic events, Puusepp was probably influenced again by ideas from psychoanalysis because, due to psychoanalytical studies, psychological and personal factors (rather than biological aspects) had become relevant to the research on a person's suicidal behaviour. ${ }^{47}$ One of Freud's major contributions to psychiatry is his research into trauma and his emphasis on its significance as a factor in developing mental problems. ${ }^{48}$ However, in connection with extracorporeal factors, Puusepp also believed that literature and the press had a negative affect because of the beguiling manner in which suicides were reported or depicted ${ }^{49}$ Although suicides were, indeed, frequently reported in the press and the topic of death was presented in an attractive manner, Puusepp's point of view was nevertheless - at least partly - in line with the widespread opinion among conservatives at the time that contemporary entertainment and the media were sinful and were stimulating mental degeneration. We can thus conclude that from Puusepp's point of view the environment did play a role in the emergence of suicide as a biological developmental disorder.

On the other hand, changes in temper and extreme mood swings were thought to be characteristics of human nature. Luiga claimed that melancholia was a case of "disorder in the sphere of emotions", and with this definition categorised it as a pathology. But he was also of the opinion that melancholic mood, which could lead to the loss of raison d'être, was sometimes caused in a perfectly "healthy

45 Puusepp, Noorus ja eluväärtus, 11, 20-22, 37-38, etc.

46 Ibidem, 3, 5; "Prof. L. Puusepp: Die traumatische Kriegsneurose. - Referaadid. Kirjandus", Eesti Arst, 2 (1924), 43. In the early 1920s Puusepp, who was inspired by psychoanalysis, thought of setting up a hospital for patients suffering from war trauma. Ken Kalling, "Sõjandustemaatika Eesti meditsiiniperioodikas 1920-1940 (kommenteeritud bibliograafia)", KVÜÕA Toimetised, 3 (2004), 238. After WWI broke out, which partly inspired Freud to formulate the conception of the "death drive", Freud wrote a critical article about the war. Sigmund Freud, "Thoughts for the Times on War and Death, Part I: The Disillusionment of the War" (1915), https://www. panarchy.org/freud/war.1915.html [accessed on 07.07.2020]; Jones, The Life and Work of Sigmund Freud, vol. 3, 273-274.

47 Colt, The Enigma of Suicide, 194-196, 201; Thomas Ellis, "Psychotherapy with Suicidal Patients", Suicide Prevention: Resources for the Millennium, ed. by David Lester (Philadelphia: Brunner-Routledge, 2001), 130.

48 John Fletcher, Freud and the Scene of Trauma (New York: Fordham University Press, 2013), 11-35.

49 Puusepp, Noorus ja eluväärtus, 16-17. 
mind" by a traumatic experience such as a break-up or the death of someone close. ${ }^{50}$ He believed it to be a mental illness only if the person had prolonged sadness and despondency for no obvious reason, ${ }^{51}$ was "suffering and changing as a whole", 52 referring to what today we define as a personality disorder or depression. Similar statements were made by contemporary doctors like Emil Kraepelin and Freud. The latter, who studied both trauma and melancholia as psyche-related issues, argued that there is a normal reaction to the loss of loved one or something more abstract such as an ideal, manifested in immense sadness or mourning. But this condition was transient. Melancholia was rather a permanent pathological condition characterised by low self-esteem, disinterest in the outside world, a decrease in activity and an incapability of feeling love. ${ }^{53}$ Kraepelin, who researched melancholia, developed a similar point of view. He had claimed before Freud that "morbid emotions" - unlike "normal emotions" - often evolve without any particular reason and are intense and enduring. ${ }^{54}$ However, Freud and Kraepelin had different approach to mental illnesses. While Kraepelin emphasised the biological aspects of mental illness and focused on collecting clinical data, Freud on the other hand emphasised the psychological aspect, leading to the importance of therapy (the so-called 'dialogue' between the patient and the therapist). ${ }^{55}$ Kraepelin, who worked at Tartu University between 1886 and 1891, came up with a classification of mental illnesses and was the first to describe schizophrenia

50 Luiga, "Haiguslikud ilmed terves inimhinges", 15-16.

51 Luiga, "Ihu ja hinge vahekord", 42.

52 Luiga, "Haiguslikud ilmed terves inimhinges", 15.

53 Freud argued that both mourning and melancholia emerged from loss, but melancholia results from not overcoming a loss. Sigmund Freud, "Mourning and Melancholia" (1917), 153155, http://www.columbia.edu/itc/hs/medical/clerkships/psych/misc/articles/freud.pdf [accessed on 07.07.2020]; Flatley, Affective Mapping. Melancholia and the Politics of Modernism, 2, 41-50; Radden, Moody Minds Distempered. Essays on Melancholy and Depression, 147-162.

54 Allen Ross Diefendorf, Emil Kraepelin, Clinical Psychiatry: A Text-book for Students and Physicians (New York: Macmillan, 1902), esp. 49, 254-261; Allan V. Horwitz, Jerome C. Wakefield, Lorenzo Lorenzo-Luaces, "History of Depression", The Oxford Handbook of Mood Disorders, ed. by Robert J. DeRubeis, Daniel R. Strunk (Oxford: Oxford University Press, 2017), 16.

55 Flatley, Affective Mapping. Melancholia and the Politics of Modernism, 42; Paul Hoff, "The Kraepelin Tradition”, Dialogues Clin Neurosci, 17 (1) (2015), 31-41, https://www.ncbi.nlm.nih. gov/pmc/articles/PMC4421898/ [accessed on 07.07.2020]; Georg Northoff, "Psychoanalysis and the Brain - Why did Freud Abandon Neuroscience?", Front Psychol, 3 (2012), 1-11, doi: 10.3389/ fpsyg.2012.00071. 
("dementia praecox" in those days) and the bipolar disorder ("manic depression", which included melancholia). ${ }^{56} \mathrm{He}$ also began using the term "depression" instead of "melancholia", which became the preferred term in the field of psychiatry in the first decades of the $20^{\text {th }}$ century. ${ }^{57}$

The emerging interest in mental health issues in Estonia was directly in line with the degeneration theories that created repercussions across Europe. According to these theories, modern civilisation was degenerating due to the spread of 'sickly' manners and views of life and because people were struggling with various diseases. These perceptions found their way into medical circles and cultural and social discussions. These discussions also affected the field of art. People with a more conservative view of life regarded modern art, which had moved away from traditional manners of creation and aesthetics and hence abandoned traditional values, to be an important indicator of the degeneration of society. ${ }^{58}$ Works by a modern/new artist could therefore be interpreted as creations of a sick mind. Max Nordau, the best-known degeneration theoretician, considered modern art (especially symbolism) to be degraded and condemned modern artists as degenerate imbeciles. ${ }^{59}$ Luiga, who agreed with Nordau's ideas, was concerned that people with mental issues were often not identified as such and that "some interesting mentally feeble, degenerate" persons were even highly appreciated. Luiga specified that he was mainly speaking about the world of literature: according to Luiga it was $19^{\text {th }}$-century France where "the onset of

56 See about Kraepelin's research on melancholia: Radden, The Nature of Melancholy: From Aristotle to Kristeva, 259-279. Maike Rotzoll, Frank Grüner, "Dorpat University in the Late Nineteenth Century as a Transit Space for Psychiatric Knowledge. The Example of Emil Kraepelin and His Conceptualization of Melancholia”, Explorations in Baltic Medical History, 1850-2015, ed. by Nils Hansson, Jonatan Wistrand (New York: University of Rochester Press, 2019), 170-185.

57 Rotzoll, Grüner, "Dorpat University in the Late Nineteenth Century as a Transit Space for Psychiatric Knowledge. The Example of Emil Kraepelin and His Conceptualization of Melancholia", 176.

58 In the eyes of conservatives, everything and everyone that undermined bourgeois values, manners and changed social and cultural practices was seen as problematic. As well as the aesthetic changes that took place within the art field, socio-political movements and their representations, like the emancipation of woman, were seen as signs of a degenerative society. Mirjam Hinrikus, Dekadentlik modernsuskogemus A. H. Tammsaare ja nooreestlaste loomingus. Dissertation (Tartu: Tartu Ülikool, 2011), 14-15.

59 Max Nordau, Degeneration (New York: D. Appleton and Company, 1895 [1892]), 118, see also $100-144$. 
the madness took place" with the emergence of Charles Baudelaire. ${ }^{60}$ His view that younger Estonian writers were also trying to emulate that French culture was a widespread allegation against creators of modern art in Estonia, for whom French visual arts and literature served, indeed, as a model. Luiga feared that Estonian culture would gradually vanish, because the cultural production of smaller nations was regarded as inferior and therefore the representatives of such cultures felt the impulse or need to imitate the 'great' cultures. ${ }^{61}$ Among such 'imitations' were depictions of the symptoms of the so-called nervous era, which began emerging in Estonian literature and art at the end of the first decade of the $20^{\text {th }}$ century, although this was not simply due to familiarity with the works of foreign artists, but also because of the above mentioned factors. This strong interest in the human psyche and ideas about mental health problems helped increase the significance of the emotional component in art and brought phenomena regarded as pathologies into the artists' focus, inspiring them to depict melancholia.

\section{BODILY REPRESENTATIONS OF MELANCHOLIA}

In decadent art, psychological states and emotions are mainly expressed through different body parts. The body has always been a central motif in visual arts and various means of expression from the domain of body language have found their way into art: facial expressions, gazes, poses, gestures, but also clothing, make-up and hair styles. There is a tradition in rendering the body which contributes to the expressiveness of the human figure, "on its ability to embody the ideals of beauty and the timeless stories and emotions of mythology", 62 and person's mood states.

However, there were several factors within the context of the period in question that nurtured the depiction of psychological

60 Juhan Luiga, "Vaimuhaiged: I. Sissejuhatuseks", Mäss ja meelehaigus, ed. by Hando Runnel (Tartu: Ilmamaa, 1995 [1901]), 28-29.

61 Juhan Luiga, "Rahvaste tõus ja langemine”, Mäss ja meelehaigus, ed. by Hando Runnel (Tartu: Ilmamaa, 1995 [1910]), 224-225.

62 Tiina Abel, "Introduction", Kehakeeles: töid Tartu Kunstimuuseumi kogudest = The Eloquent Body: Works from the Collections of Tartu Art Museum, ed. by Tiina Abel (Tartu: Tartu Kunstimuuseum, 2017), 130. See about attitudes towards bodies in different historical periods from the book: The Body in History, Culture, and the Arts (Routledge Studies in Cultural History), ed. by Justyna Jajszczok, Aleksandra Musiał (New York: Routledge, 2019). 
issues through body parts. For example, there has been widespread perception since the end of the $19^{\text {th }}$ century that a person's character, morality, mental state and even social status can be identified through his or her physiognomy. These characteristics were believed to manifest themselves in the size of a person's skull or in the shape of their lips and nose, etc. ${ }^{63} \mathrm{I}$ addressed the issue in the article Violence Against Women in Estonian Decadent Art (Naistevastane vägivald Eesti dekadentlikus kunstis, 2019) ${ }^{64}$, where I analysed how violence against women has been visualised in art. It became evident that in many cases a person or a fictional creature with a violent character was depicted as having a grotesque physique. The pictures reflected the idea that the inner being of a person was evident on the outside. A similar thought can be found, for example, in Oscar Wilde's decadent novel The Picture of Dorian Gray (1890). Dorian's lousy character is not reflected in his appearance, which retains its beauty and youth, but in his portrait, which gradually becomes more and more appalling. The deformed appearance was regarded as a suitable way of highlighting horror and conveying different problems, including nightmares, "sick" (sexual) desires, and various pathologies. This tendency appeared in decadent art from the turn of the $19^{\text {th }}-20^{\text {th }}$ centuries. Consider, for example, Aubrey Beardsley's and Edvard Munch's stretched-out and disfigured bodies based on the aforementioned ideas and idealised as androgynous beauty, art nouveau and Japanese aesthetics (regarding Beardsley's art). ${ }^{65}$

The distorted human figures became even more widely used in the aftermath of WWI, for example the dismembered body, which could create associations with the physical damage caused by exploding bombs and grenades, and be interpreted as the manifestation of shell shock in visual art. According to Trudi Tate, "dismembered bodies

63 Mary Cowling, The Artist as Anthropologist: The Representation of Type and Character in Victorian Art (Cambridge: Cambridge University Press, 1989), 64-65; Nicole Rafter, Chad Posick, Michael Rocque, The Criminal Brain: Understanding Biological Theories of Crime (New York: New York University Press, 2016), 70-79; Kalling, "Galerii omadest ja võõrastest: Neurasthenia estonica ja need teised diagnoosid".

64 Lola Annabel Kass, "Naistevastane vägivald Eesti dekadentlikus kunstis", Kunstiteaduslikke Uurimusi, 3-4 (28) (2019), 27-59.

65 See about androgyny: Brendan Cole, "Nature and the Ideal in Khnopff's Avec Verhaeren: Un Age and Art, or the Caresses", The Art Bulletin, 91 (3) (2009), 325-333; Hinrikus, Kass, "Summary", 231-232. Read about the influence of the Japanese aesthetics on Beardsley's art: Linda Gertner Zatlin, "Aubrey Beardsley's "Japanese” grotesques”, Victorian Literature and Culture, 25 (1) (1997), 87-108. 
are often used to signify the terror and sorrow of the frail human body facing the machinery of war". ${ }^{66}$ The negative experience of war, both as civilians and soldiers, was often visualised by artists and writers through body parts, for example by artists Otto Dix and George Grosz. ${ }^{67}$ Therefore, atrocities committed against the body (and psyche) were another reason why different phenomena perceived as negative were visualised through body image. These included melancholia and social vices like corruption, addiction to substances or gambling, war trauma, etc. Although, in addition to negative war experience, researchers have also identified medical photos as a source of inspiration for the expressionist distorted body: photos of the physical symptoms of mental disorders such as hysteria, in which grotesqueness, i.e. motor disorders and the disproportionality of body parts have been captured. ${ }^{68}$

In Estonian art melancholia was in some cases conveyed through a distorted physique, although in most cases allusions were created by means of a 'normal' body, often depicted in a hunched posture expressing lack of energy or passiveness. The emphasis was on introversion or introspection, which in visual language was expressed by means of hands crossed above the chest or palms turned towards the body, or by depicting the figure in (semi) profile. This kind of pose symbolised an unwillingness to communicate (as opposed to en face portrayal).

On the other hand, images symbolising the gravity of melancholia, such as the skeleton and the skull, were widely used, sometimes referring to suicide as a possible complication of melancholia. The skeleton is a traditional personified embodiment of death and the skull is a symbol of ephemerality, but in decadent art they were used to convey psychological states and to symbolise (because of the above associations) melancholia and grief. For example, the well-known

66 Trudi Tate, Modernism, History and the First World War (Manchester: Manchester University Press, 2013 [1998]), 92.

67 The above mentioned medical photos of patients with hysteria were mainly taken at the Pitié-Salpêtrière University Hospital under the supervision of the hospital manager Jean-Martin Charcot. Ibidem, 92, 75-131; Claude Lacroix, "The Visual Politics of the Body in Germany Between the Two World Wars", The Body in History, Culture, and the Arts, ed. by Justyna Jajszczok, Aleksandra Musial (New York: Routledge, 2019), 85-105.

68 Frank J. Erbguth, "Egon Schiele and Dystonia", Neurological Disorders in Famous Artists, part 3, ed. by Julien Bogousslavsky, Michael G. Hennerici, Hansjörg Bäzner, Claudio Bassetti (Basel, Paris, London, etc.: Karger, 2010), 47-48; Nathan J. Timpano, Constructing the Viennese Modern Body: Art, Hysteria, and the Puppet (New York, London: Routledge University Press, 2017), 9-11. 
FIG. 4. GORI, GRIEF, INDIAN INK ON PAPER (1919). $29.5 \times 32.5$ CM. UNDER AND TUGLAS LITERATURE CENTRE. PHOTO: TOOMAS TUUL.

Estonian caricaturist Gori used the image of a skeleton collapsing from sadness to depict mourning in his drawing Grief (Lein, 1919, Fig. 4). The skeleton and the skull were used by Nikolai Triik, one of the most renowned early- $20^{\text {th }}$-century artists in Estonia, to depict suicide in two pictures he made in 1927: November (Kooljakuu, Fig. 5) and Self-Murderer (Enesetapja, Fig. 6). The Indian ink drawings were made to illustrate poems by the same titles in Marie Under's collection of poems A Voice from the Shadows (Hääl varjust, 1927). ${ }^{69}$ In

69 Influences of German expressionism and WWI have been identified in Under's poems; the above mentioned poems partly bear those influences, too. Tiina Kirss, "Inimkonna hämarus: saksa ekspressionistliku luule siirded Marie Underi loomingus", Methis: Võrdleva kirjanduse erinumber, 17/18 (2016), 126-144. Triik illustrated the whole collection of poems Hääl varjust. Triik and Under both were members of the modern literary group named Siuru, whose logo was designed by Triik. 
FIG. 5. NIKOLAI TRIIK, NOVEMBER, GRAPHITE, INDIAN INK AND SEPIA ON PAPER (1927). 33.7 $\times 26.5$ CM. UNDER AND TUGLAS LITERATURE CENTRE. PHOTO: TOOMAS TUUL. 


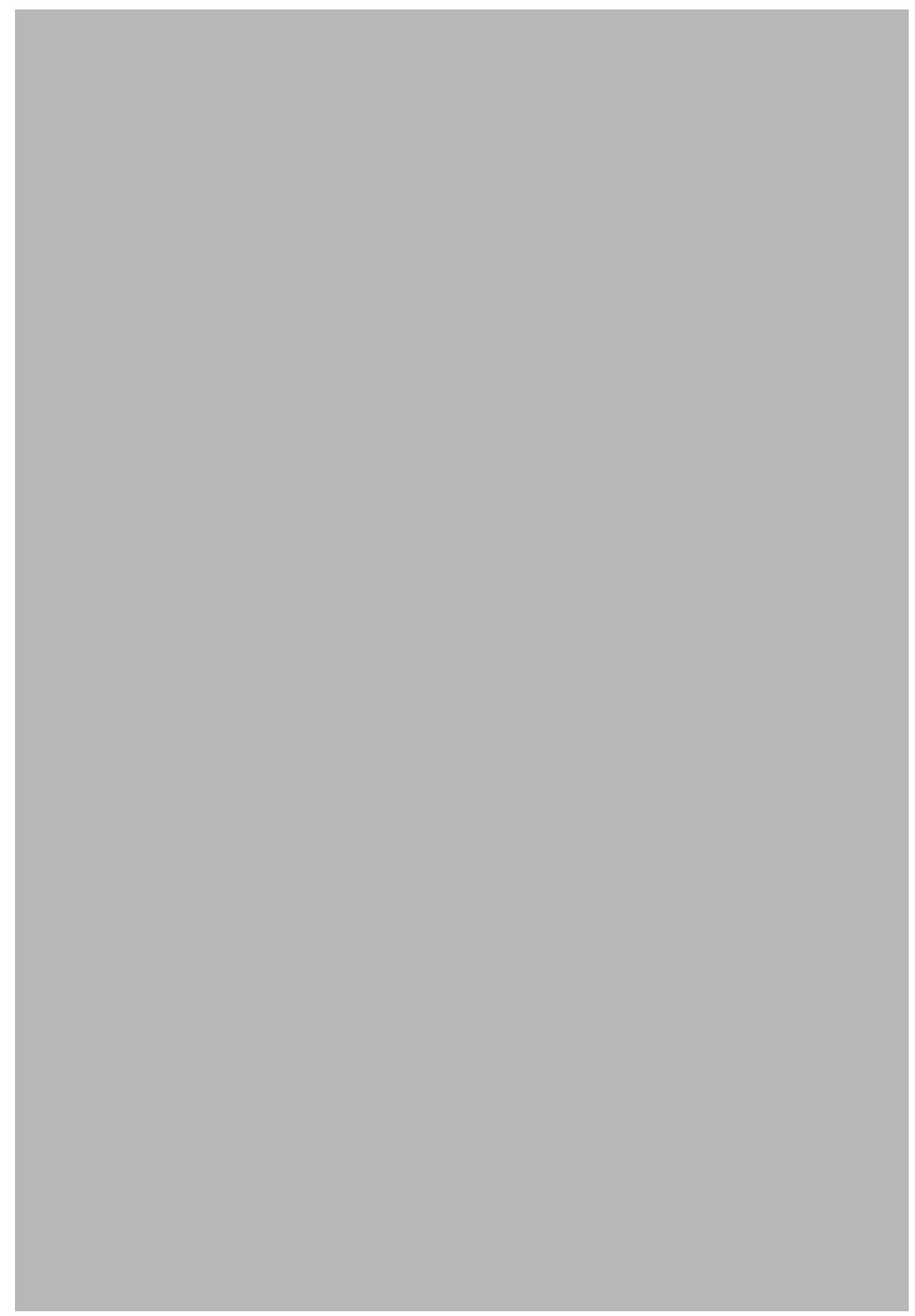

FIG. 6. NIKOLAI TRIIK, SELF-MURDERER, GRAPHITE, INDIAN INK, SEPIA ON PAPER (1927). $33.7 \times 26.5$ CM. UNDER AND TUGLAS LITERATURE CENTRE. PHOTO: TOOMAS TUUL. 
November a person dead by hanging has been depicted as a skeleton hanging from a tree. On the other hand, the picture also refers to what November used to be called in the old Estonian tradition - the month of the dead. There is a line in Under's poem which says: "the moon so heavily hangs from the tree", ${ }^{70}$ and in Estonian the words moon and month are both translated as kuu. Therefore, the skeleton could also be a personification of the month of November. Yet, just as the scene in the picture clearly refers to suicide, the poem speaks about "the mood of despair", for which the author found inspiration in Baudelaire's poem Spleen: I am Like the King (Spleen: Je suis comme le roi, 1857). ${ }^{71}$ Baudelaire writes about the weariness of life and uses the image of a skeleton to describe that state of being by saying that a person weary of life is like "a skeleton, a cadaver, in whose veins flows the green water of Lethe in place of blood."72 Triik's second drawing, Self-Murderer, depicts a person with eyeholes reminiscent of a skull and a huge skeleton walking behind the human figure like a shadow. On the basis of the poem's text as well as the positioning of the figures in the picture it is clear that the skeleton symbolises suicidal thoughts: there is a connection between the two figures created by the dark blotch on the ground uniting them at the feet and a similar gesture of the right hand raised to the chest. The dagger in the person's hand also clearly refers to suicide. There are lines in Under's poem, too, that refer to insuperable wish to die: "The hour has come, /---/ that drained strength from my flesh and bones, /---/ There is a hole in my heart - and it is death." 73

The traditional melancholia pose is also widespread in depictions of this condition. The best-known example of it is probably Albrecht Dürer's copper engraving Melancholia I. (Melencolia I, 1514): sombreness has been conveyed through the melancholia pose characterised

70 Marie Under, “Kooljakuu”, Hääl varjust (Eesti Kirjanikkude Liit, 1927), 28.

71 There are many similarities between the two poems and the illustration, in addition to the skeleton e.g. the Lethe river that Under refers to in the line "blood turned into water, the heart cooled". Cf. Baudelaire: "He /---/ in whose veins flows the green water of Lethe in place of blood". Under has also translated Baudelaire's poems: "Väikesed poeemid proosas" (Tartu: G. Roth, 1930).

72 Charles Baudelaire, "Spleen: I am like the king...", transl. "Spleen: Je suis comme le roi" by William Aggeler, Fleurs du Mal/Flowers of Evil (Fresno, CA: Academy Library Guild, 1954, [1857]), available online at https://fleursdumal.org/1857-table-of-contents [accessed on 08.07.2020].

73 Marie Under, "Enesetapja”, Hääl varjust (Eesti Kirjanikkude Liit, 1927), 79. 
by a thoughtful gaze, a slanting head resting on one hand and a resigned posture ${ }^{74}$ There are variations of the pose with the tilted head as the focal point, for example Odilon Redon's picture The Marsh Flower, A Head Sad \& Human (La Fleur du marécage, une tête humaine et triste, 1885). In Estonia, several artists have used the traditional melancholia pose, including one of the best-known decadent artist Eduard Wiiralt, whose watercolour painting Melancholy (Melanhoolia, 1917, Fig. 7) depicts a sullen-looking woman with a tilted head, her stretched fingers gently touching the forehead. Another compelling work by Wiiralt is an ink drawing titled Artist (Kunstnik, 1917, Fig. 8), which depicts a male artist who seems to be melancholic. In addition to the traditional melancholia pose used, this work is interesting because it clearly implies the concept of the suffering genius. Wiiralt emphasises both creativity and mood. The artist tools and aesthetic surroundings depicted - flower elements and geometric patterns of the space - refer to the occupation. The drooping flowers tie in with the artist's impotent posture and inclined head, helping to create an imaginary melancholic atmosphere. The inclined head and semi-profile show his subdued spirit and deep thoughtfulness, his intellectuality.

Moreover, such a posture seems to suggest that the head is so full of restless or intrusive thoughts that it has become heavy with the burden. ${ }^{75}$ Something similar can be found in texts that have an emphasis on a constant accumulation of thoughts. Baudelaire elaborates on spleen or life fatigue: "I have more memories than if I'd lived a thousand years. /---/ A heavy chest of drawers cluttered with balance-sheets, processes, love-letters, verses, ballads, and heavy locks of hair enveloped in receipts, hides fewer secrets than my gloomy brain. /---/". ${ }^{76}$ Drawers stuffed with things symbolise the head filled with stifling thoughts and memories, although the

74 The traditional melancholia pose is thousands of years old. Raymond Klibansky, Erwin Panofsky, Fritz Sax1, Saturn and Melancholy: Studies in the History of Natural Philosophy, Religion, and Art, ed. by Philippe Despoix, Georges Leroux (Montreal, London, Chicago: McGill-Queen's University Press, 2019 [1964]), 286-289; Aleksandra Kounty-Jones, Visual Cultures of Death in Central Europe: Contemplation and Commemoration in Early Modern Poland (Lithuania. Boston: Leiden: Brill, 2015), 56-65.

75 It seems to be the case with Dürer's work. Klibansky, Panofsky, Saxl, Saturn and Melancholy: Studies in the History of Natural Philosophy, Religion, and Art, esp. 317-318, 286-287.

76 Charles Baudelaire, "Spleen J'ai plus de souvenirs...” trans. "Spleen: I have more memories..." by William Aggeler, Fleurs du Mal/Flowers of Evil (Fresno, CA: Academy Library Guild, 1954, [1857]). 
FIG. 7. EDUARD WIIRALT, MELANCHOLY, INDIAN INK, WATERCOLOUR ON PAPER (1917). 10.6 $\times$ 8.4 CM. ART MUSEUM OF ESTONIA. PHOTO: STANISLAV STEPAŠKO. 


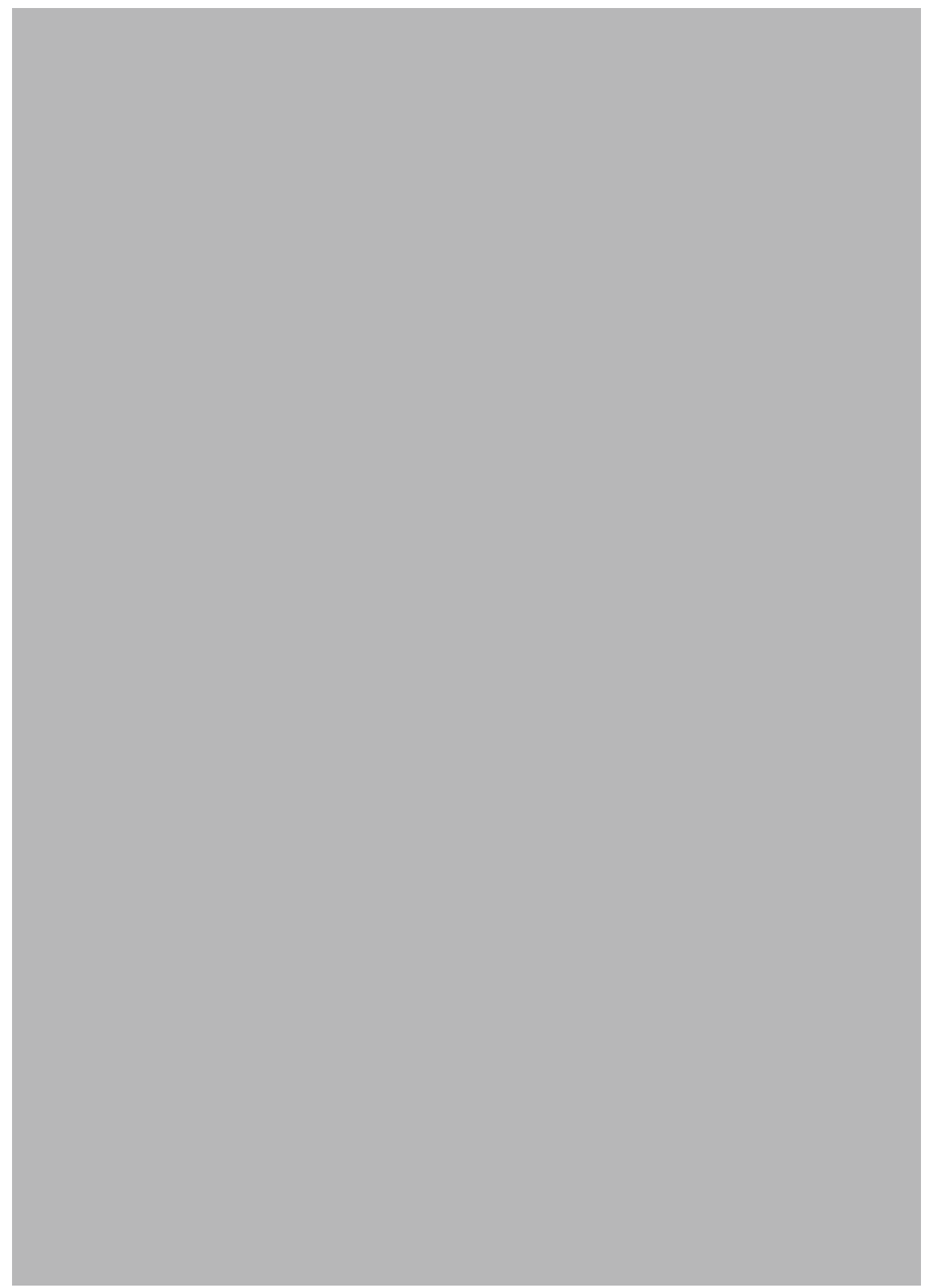

FIG. 8. EDUARD WIIRALT, ARTIST, INDIAN INK ON PAPER (1917). $14 \times 11.7$ CM, ART MUSEUM OF ESTONIA. PHOTO: STANISLAV STEPAŠKO. 
heavy heart motif is also often used, metaphorically placing the stifling feeling in the chest. A similar leaden feeling can be felt all over the body, pulling it towards the ground. It is often visualised with a bent body and tilted head arching towards the ground or by adding various elements that emphasise heaviness.

The emphasis on the head is probably also due to the fact that it represents the body and the human being as a whole: an evocative head is enough to convey a mood. ${ }^{77}$ This is achieved using different parts of the head, eyes as mirrors of the soul in particular. Therefore, to convey melancholia, artists often resort to highlighting the gaze, which can be sad, gloomy or turned away and fixed on the distance. Moreover, as was mentioned in regard to Triik's pictures (Fig. 1, Fig. 6), the look can be empty and the eyes can be replaced by skull-like eye sockets. This technique was actually favoured by Munch, who was highly appreciated by several Estonian artists, including by Triik. ${ }^{78}$ Munch used eye sockets in human faces to depict a sense of sullenness, fatigue and a more general gloominess, for example in his paintings The Deathbed (Ved dødssengen, 1895) and Self-Portrait. The Night Wanderer (Selvportrett. Nattevandreren, 1923-1924). But if we observe how the gazes of the figures in the pictures are in dialogue, we discover how the artist has joined them together into a meaningful whole. For example, in Triik's drawing Self-Murderer the hanging skeleton and the bellowing cow - the symbol of death - are facing one another (cf. Fig. 3 and 10). In another of Wiiralt's works on melancholia, titled Painter (Maalija, 1918, Fig. 9), it is the painter's half-closed eyes looking at the empty canvas in front of him that are the most eloquent, becoming a symbol of artist's block. However, the painter himself is being watched by three birch trees. The latter have been given eyes in form of holes that have a similar omen-like function as the eye sockets in skulls.

77 Hugh Aldersey-Williams, Anatomies: A Cultural History of the Human Body (New York, London: W. W. Norton \& Company, 2013), 84, 86.

78 Based on studying art criticism of the early $20^{\text {th }}$ century, I can state that Munch was probably the first foreign artist whose creation was thoroughly reviewed. Bernhard Linde, "Edvard Munch", Vaba-Sõna (1915), 100-109. Munch's example for Estonian art has been pointed out repeatedly by art reviewers, during the period under examination, and by several Estonian art historians. 
FIG. 9. EDUARD WIIRALT, PAINTER, INDIAN INK, WATERCOLOUR ON PAPER (1918). $24.4 \times 18.1$ CM. ART MUSEUM OF ESTONIA. PHOTO: STANISLAV STEPAŠKO.

\section{INTERTEXTUALITY IN DEPICTIONS OF MELANCHOLIA}

Decadent works are characterised by both conscious references and unintentional allusions to various verbal, visual texts. Intertextuality serves as an amplifier to the main subject and meaning (melancholia) of the picture thanks to the use of widely known images and techniques that function as signs, because they generate similar associations. Some of the intertextual links were mentioned in the previous chapter, such as the traditional melancholia pose that expresses gloomy mood, or the expressive-grotesque body associated with trauma, melancholia or illness more generally; the intertextuality of Baudelaire's poetry was also dealt with.

It is important to notice details and the intertextuality of images because they may denote moods and psychological conditions, as became evident in the above described drawings by Triik. In 
his pictures Self-Murderer (Fig. 6) and November (Fig. 5) the death message is presented in the image of the skeleton as well as the bellowing cow, but also in depictions of the Lethe River and Calvary: mythological and religious symbolism is widespread in decadence. Calvary is clearly present in Self-Murderer as the cross on top of a hill. In November the same image is represented by a windmill, which is in conformity with the line in the poem it illustrates: "the windmill in the shape of the lethal cross". ${ }^{79}$ Calvary is an interesting motif that the artist has also used in another work that depicts suicide: Howling Dog (Ulguv koer, 1921, Fig. 10), in which one can see, in addition to the howling dog, a man playing the violin, a hanging rope and the gallows. Hanging was one of the most widely used way to commit suicide among men ${ }^{80}$ and it was an important topic in Estonian art and literature of the period in question. The meaning of the gallows and the rope are evident, but the use of Calvary as an image may hint at carrying a heavy load of worries, which in this case has led to suicide. In this context the widespread image of the violin is also noteworthy: it is often used to symbolise a melancholic mood because the sound of the violin may be reminiscent of a sad or tortured human voice. ${ }^{81}$ The violin and violinist are leitmotifs in Triik's art as well as in the work of his student Wiiralt, where they have many symbolic meanings and may also refer to melancholia. ${ }^{82}$

Another common trait in Triik and Wiiralt's artwork is the use of natural imagery in emphasising melancholia: scenes and characters have been outlined against the background of a natural landscape. Although natural imagery has played a central role in visual arts through different periods of history, expressing emotion through images of nature was a trend initiated by romanticism in the $19^{\text {th }}$ century. The trend did not subside in Europe at the onset of the $20^{\text {th }}$ century. In decadent landscape painting as well as in the use of natural imagery there is an understanding that nature gives rise to

79 Under, "Kooljakuu", 28.

80 "Kroonika - Enesetapmiste arvustik Eestis 1920-22", Eesti Arst, 4 (1923); Ibrus, "Mõnda enesetappest", 40.

81 Bart Pushaw, Värvide dirigendid: muusika ja modernsus Eesti kunstis = Conductors of Colour: Music and Modernity in Eestonian Art (Tallinn: Eesti Kunstimuueum, 2016), 30-31.

82 See Triik's work titled The Way of Death (Surma viis, 1911-1912, Tartu Art Museum) and Wiiralt's Violinist (Viiuldaja, 1929, Estonian Art Museum). Estonian art is available online at https://www.muis.ee/en_GB/ [accessed on 08.07.2020]. 


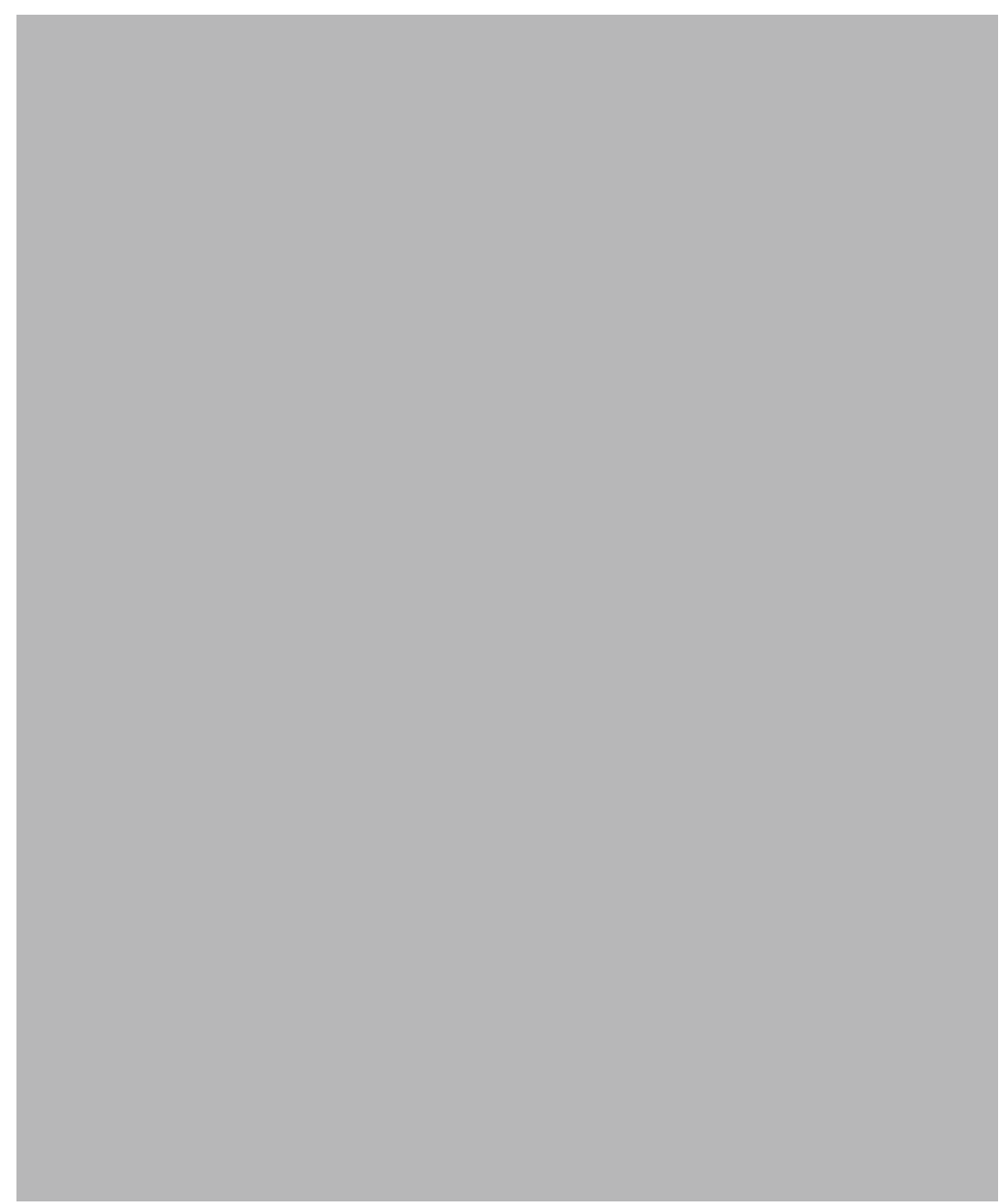

FIG. 10. NIKOLAI TRIIK, HOWLING DOG, INDIAN INK, SEPIA, WATERCOLOUR ON PAPER (1921). 42.5 × 35.7 CM. TARTU ART MUSEUM. PHOTO: TÕNU TAMM. 
emotion, but is at the same time a source of inspiration and a means of conveying the newly acquired vision or the psychological state of the artist/character. ${ }^{83}$ It is interesting to note that researchers of decadent literature have pointed out a special feature of Nordic decadence: an abundance of natural images and the significance of local scenery in the act of psychologising. ${ }^{84}$ The same can be said about decadent visual arts in Scandinavia and the Baltics. ${ }^{85}$

The tendency to depict moods and emotions metaphorically through images of nature was fuelled by a number of theories and studies - both past and contemporary - that focussed on finding a connection between climate and nature on the one hand and the psyche, temperament or breed on the other. The theory of the four temperaments or Humours, which dates from antiquity, has for centuries influenced artists and writers. A person's temperament and health were believed to be dependent on the balance of bodily fluids and their respective temperament types: blood and sanguine (Latin sanguis), phlegm and phlegmatic (Greek phlegma), black bile and melancholic (Greek melaina cholē), yellow bile and choleric (Greek cholē). A human being becomes melancholic when the spleen secretes too much black bile. ${ }^{86}$ As a legacy of that theory the decadent artists associated melancholia with autumn. Namely, the four temperaments model paired each type of

83 See "Preface" and Anna-Maria Bonsdorff's article "Dream Landscapes: From Fantasy Worlds to Nightmares" in Van Gogh to Kandinsky: Symbolist Landscape in Europe 1880-1910, ed. by Richard Thomson, Rodolphe Rapetti, Nienke Bakker, Anna-Maria von Bonsdorff (London, New York: Thames and Hudson, 2012). In addition, city landscapes were also depicted in decadent art to reference the idea that living in the city might cause health problems such as melancholia and anxiety. See from aforementioned book Frances Fowle's article "Silent Cities".

84 Nordic Literature of Decadence, 85. In contrast, there is much artificiality in the decadent literary works of the more prosperous and deeply urbanised and technologised Western countries: the description of feelings and surroundings through human-made objects. A good example is the aforementioned Baudelaire's poem "Spleen: I have more memories...", in which the boudoir with a drawer and letters symbolised melancholia.

85 For example, nature landscapes are typical of Munch's art, while in Estonia artist Konrad Mägi used nature to depict melancholia; he also associated this mood with Northland and Nordic nature. Lola Annabel Kass, "Värvikas raskemeelsus Friedebert Tuglase ja Konrad Mägi looduspildis" [forthcoming]. See about the importance of nature in Baltics art: Vabad hinged: sümbolism Baltimaade kunstis = Wild Souls: Symbolism in the Art of the Baltic States, ed. by Liis Pählapuu (Tallinn: Eesti Kunstimuuseum, 2018).

86 Melancholia was defined as a permanent condition (temperament) that was caused by lesser and stable imbalance of the bodily fluids and an illness that was caused by a temporary excess of black pile. See Radden, The Nature of Melancholy: From Aristotle to Kristeva, 55-68; Jacques Jouanna, Greek Medicine from Hippocrates to Galen. Selected Papers (Leiden: Brill, 2012), esp. chapters "At the Roots of Melancholy: is Greek Medicine Melancholic?", "Hippocratic treatise The Nature of Man: the Theory of the Four Humours". 
temperament up with seasons and the melancholic type was matched up with autumn.

On the other hand, the link between melancholia and autumn and the Nordic countries could have been reinforced by the theories of relationship between climate and breed and psyche. For example, the historian and critic Hippolyte Taine claimed that a tendency to melancholia and pessimism were inherent in the Nordic breed as well as in that of the Slavic and Germanic peoples. ${ }^{87}$ He believed that this trait in the northerners was caused by climatic and natural circumstances, which were difficult to adapt to. ${ }^{88}$ Hence, living conditions and the environment were responsible for the peculiarities of each breed. ${ }^{89}$ The Nordic climate of Estonia can be likened to autumn for the majority of the year: short of light, rich in clouds, damp and chilly.

Medicine could also have influenced artists, although it never confirmed the role of autumn in developing melancholia. On the contrary, early $20^{\text {th }}$-century scientists and doctors studied the frequency of suicides by season but did not come up with a common conclusion or justification. Nevertheless, it is evident from various texts that the number of suicides might have risen drastically in autumn, but it did so even more in spring and summer. ${ }^{90}$ It is significant, therefore, that Wiiralt's Melancholy (Fig. 7) is set in a brightly coloured blossoming season: although autumn was more widespread in representations of depressiveness, there were exceptions to the rule.

In decadence, natural images most often used to convey melancholic shades of emotions are clouds, evening skies, rocks and peculiar trees. For example, in Triik's drawing Howling Dog (Fig. 10) the necessary

87 Nordic Literature of Decadence, 27.

88 Ibidem.

89 Taine argued that human behaviour and mentality were shaped by race (la race), but the race characteristics were also affected by environmental conditions (milieu) and historical moment or social circumstances (le moment). He was convinced that all three aspects had also an effect on art: artworks reflect an artist's nature, soul and era. The role of environment (incl. climate), ethnicity or breed was important aspect in art history writings since the middle of the $19^{\text {th }}$ Century. Hippolyte Taine, The Philosophy of Art, transl. by John Durand (New York: Holt \& Williams, 1873 [1865]) available online at http://www.gutenberg.org/files/52980/52980h/52980-h.htm [accessed on 10.07.2020]; Thomas DaCosta Kaufmann, Toward a Geography of Art (Chicago, London: University of Chicago Press, 2004), 44, 43-67; Mirjam Hinrikus, "Decadent Modernism and the Imprint of Taine in Aino Kallas' "Young Estonia: Portraits and Trajectories"', Aino Kallas: Negotiations with Modernity, ed. by Lea Rojola, Leena KurvetKäosaar, (Helsinki: Finnish Literature Society, 2011), esp. 76-77, 69-93.

90 E. D., "Kuritöö ja aastaajad", "Sõnumete” lisa, 18.09.1906, 155-156; Puusepp, Noorus ja eluväärtus, 14; Ibrus, "Mõnda enesetappest”, 38; Lellep, "Kuritegevus Eestis", 16-18; "Kas enesetapmine on patt?"; Colt, The Enigma of Suicide, 190. 
dramatic effect is achieved through the romanticist triangular composition with a bright explosion of light depicting sunrise in the peak of the triangle. Sunset as the prelude to the darkness of night is a frequently used image in renditions of solemnity and sullenness. ${ }^{91}$ By way of contrast, there are also innumerable visualisations of sunrises in spiritualistic-mystical works (which belong to decadence), where the depiction of sunrise evokes pious sentiment as well as ecstasy. But Triik also creates gloominess through robustly sketched clouds that he lays out across the sun like an arch. Clouds are among the most frequently used signs of melancholia. Since the $19^{\text {th }}$ century, when meteorologists as well as artists began zealously studying clouds, both artists and writers have used them to create a certain mood and indicate feelings. ${ }^{92}$ Since clouds are a sign of autumn, which overshadows and fogs sunlight, which is associated with joy, warmth and energy, they are a perfect symbol of low spirits.

Earthly objects are just as significant as heavenly ones. I already mentioned the bizarre looking trees with eyeholes in Painter (Fig. 9), but in Wiiralt's Melancholy (Fig. 7) there is a birch tree whose slanting leaves harmonise with the woman's tilted head to emphasise her feeling of melancholia - just as the flowers in Artists pose (Fig. 8). The tree from which the skeleton is hanging in Triik's November (Fig. 5) is also eyecatching and meaningful because it emphasises gloom with its pitch black leaves drawn in expressive lines. Gloomy and also nightmarish atmosphere is often visualised both in art and literature through weirdly shaped trees, such as trees with branches like long arms. For example, the painting Sorrow (Sielvartas, 1906) by the Lithuanian artist Antanas Žmuidzinavičius depicts a melancholic figure sitting in the middle of a burnt forest while long-fingered and long-armed trees try to grab him.

Rocks are another significant object that many suicides put into their pockets before drowning themselves. In addition to this tragic fact it is probably because of their coldness or heaviness that rocks have come to be associated with melancholia. A sufficiently large and grey or dark rock renders a painting a certain oppression. In addition, words like 'cold', 'weighing down' and 'a sense of heaviness'

91 Ingrid Sahk, Loodus pildis: maastikumotiivid eesti kunstis 1890-1919. Master's Thesis (Tartu: Tartu Ülikool, 2005), 34, 57-62.

92 Mary Jacobus, Romantic Things: A Tree, a Rock, a Cloud (Chicago: The University Press, 2012), 10-20, 27-31; Kass, "Värvikas raskemeelsus Friedebert Tuglase ja Konrad Mägi looduspildis". 
belong to the vocabulary used to describe melancholia. ${ }^{93}$ In Estonian there is even an specific word that references this, raskemeelsus, which translates directly into English as "heaviness of the mind" or "heavy-mindedness". In Estonian art ${ }^{94}$ and mythology rocks are associated with sadness, gloominess. Such an association is present in the Estonian national epic Kalevipoeg (Son of Kalev, 1853) written by Friedrich Reinhold Kreutzwald. One of the best-known scenes from the epic poem is the one in which the mother of Kalevipoeg, Linda, mourns her husband Kalev and carries a huge stone to his grave. This scene inspired Oskar Kallis to paint one of the most famous pictures depicting events from the epic poem: Linda Carrying a Stone (Linda kivi kandmas, 1917). It is also interesting that the rock image as well as Calvary hill are represented in each one of the above mentioned pictures by Triik, and the placement of the rock near the self-murderer as well as the massiveness of the rock emphasise the distressed figure. Wiiralt's melancholic painter is sitting on a big blue rock (Fig. 9) and rocks surround Dürer's figure, too. It is noteworthy that the four Humours theory paired each type of temperament up with a basic element (fire, water, earth, air) and elemental qualities (hot, cold, wet, dry) and earth, cold and dry were associated with the melancholic. ${ }^{95}$ Therefore rock is a suitable symbol of this mood or mental condition.

\section{COLOUR AS A SIGN OF MELANCHOLIA}

Colours play an important role in conveying emotions and moods and creating an atmosphere in decadent visual arts as well as

93 A sense of heaviness and words referring to this feeling are used to describe a melancholic state and character type. See, for example, the aforementioned poem by Baudelaire "Spleen: I have more memories...". Diefendorf, Kraepelin, Clinical Psychiatry: A Text-book for Students and Physicians, 260; Jaan Undusk, Eesti kirjanike ilmavaatest (Tartu: Ilmamaa, 2016), 332 333; Klibansky, Panofsky, Sax1, Saturn and Melancholy: Studies in the History of Natural Philosophy, Religion and Art, 420.

94 Estonian artist Aleksander Uurits has depicted rocks several times in his dark artworks, such as drawings titled Dream (Unenägu, 1909 and 1912, Estonian Art Museum) and Johannes Võerahansu in his work Melancholia (Melanhoolia/Melancolie, 1920, Tartu Art Museum). Another interesting example is sculptor Jaan Koort's work Melancholy (Melanhoolia, ca. 1909, lost): a huge melancholy looking head is placed on the top of a mound of stones. See a reproduction of the sculpture: Noor-Eesti, 3 (1909), 201, http://www2.kirmus.ee/nooreesti/uus/sirvi.php?id=465\&next=109 [accessed on 08.07.2020].

95 Elements (black bile, autumn, earth) associated with melancholia were characterised as cold and dry; Földényi, Melancholy, 89; Jouanna, Greek Medicine from Hippocrates to Galen. Selected Papers, 149, 230, etc.; Undusk, Eesti kirjanike ilmavaatest, 332. 
literature. ${ }^{96}$ The artists and writers of the period were influenced by perceptions that were fashionable at the time, as well as by those that had established themselves over the centuries. In decadent works melancholia is often expressed through shades of grey and black, which have been associated in different cultures with negative feelings and phenomena for ages, for example with (personified) evil, despondency and hopelessness; ${ }^{97}$ grey is also associated with monotony (as one of the signs of melancholia) and autumn weather.

The associations and feelings generated by colours are influenced by culture, i.e. established symbolic meanings are attached to them. Although there are biological mechanisms that govern how colours are seen and perceived, there is no purely biological determination as to what meanings and evaluations are given to them and how they are experienced on an emotional level. That depends on the cultural environment which determines how colours are interpreted. A good example here is yellow, which is regarded as an autumnal shade of colour. ${ }^{98}$ Yellow is a central colour in the autumnal palette, and in Western culture it has quite a few negative meanings and interpretations. Sulphur yellow, for example, has been the tint of Satan in sacred art, and marginalised and outcast social groups have had to mark themselves with this colour. ${ }^{99}$ In modern and decadent literature and art, yellow is associated with low spirits, illness and ill health, decay and death. ${ }^{100}$ These associations have been particularly strong since WWI because of the yellow of mustard gas (or in fact

96 Colourfulness gained momentum in the $19^{\text {th }}$ century when colour impressions and experiments with colour became the focal point of visual arts. Science and technology played an important role in this process synthesising new pigments in addition to the studies performed on the psychological aspects of colour. John Gage, Colour and Meaning: Art, Science and Symbolism (London: Thames and Hudson, 2001 [1999]), 11; Anna-Maria Bonsdorff, Colour Ascetism and Synthetist Colour: Colour Concepts in turn-of-the-20 $0^{\text {th }}$-century Finnish and European Art. D’ Dissertation (Helisnki: Helsingin yliopisto, 2012), 37-39.

97 Földényi, Melancholy, 89; Marje Tammert, Värviõpetus (Tallinn: Aimwell, 2006), 171, 173-176, 178; Radden, Moody Minds Distempered, Essays on Melancholy and Depression, 182.

98 The yellowish and withering nature of the autumn has created a connection between yellow and the theme of death. Tammert, Värviõpetus, 178. The ocher tones dominate the autumn palette. Autumn colours are combined with warmer yellow, orange, red, pink, purple, brown, green and grey. This palette contrasts with the cold colours of summer.

99 Ibidem, 160.

100 Mirjam Hinrikus, "Sissejuhatus eesti dekadentlikku kunsti", Kurja lillede lapsed. Eesti dekadentlik kunst $=$ Children of the Flowers of Evil. Estonian Decadent Art, ed. by Mirjam Hinrikus, Lola Annabel Kass, Liis Pählapuu (Tallinn: Eesti Kunstimuuseum; Eesti Teaduste Akadeemia Underi ja Tuglase Kirjanduskeskus, 2017), 41, 48-49. 
sulphur mustard). ${ }^{101}$ Because of its notoriety yellow became even the symbolic colour of decadence at the turn of the $20^{\text {th }}$ century. ${ }^{102}$ The other symbolic colour of decadence was green because of its association with absinth, ${ }^{103}$ which may, depending on its ingredients, also be greenish yellow. Oscar Wilde associated the colour green with decadence. ${ }^{104}$ It has also been regarded as the colour of poison and witches, because the latter were (since the Middle Ages) believed to have green eyes. Combinations of green and yellow can often be found in decadent works. ${ }^{105}$

In order to create emotional tension, fin-de-siècle artists began combining yellow with darker colours, including black. ${ }^{106}$ It was most frequently paired with blue, which has been the attribute of both the Virgin Mary and Satan in sacred art. ${ }^{107}$ Why Satan? Perhaps Johann Wolfgang von Goethe's colour theory will shed light on that. Goethe's 1810 book Theory of Colours (Zur Farbenlehre) was the first

101 Pirjo Lyytikäinen, Riikka Rossi, Viola Parente-Čapková, Mirjam Hinrikus, “Afterword. The Specters of Decadence in Later Nordic Literature", Nordic Literature of Decadence, 264. See artworks: Johannes Võerahansu Sitting figure (Istuv figuur, 1920s, Tartu Art Musem) and Otto Dix Skat Players (Die Skatspieler, 1920, Nationalgalerie - Staatliche Museen zu Berlin).

102 Carolyn Burdett, “Aestheticism and Decadence”, The British Library (2014), https://www. bl.uk [accessed on 08.07.2020]. A journal titled The Yellow Book was issued in the UK from 1894 to 1897 and published decadent works. The main character in The Picture of Dorian Gray reads a yellow book, which according to Oscar Wilde was the so-called bible of decadence: Joris-Karl Huysmans' novel Against Nature (’̀ rebours). Patrick Bratlinger, The Reading Lesson: The Threat of Mass Literacy in Nineteenth Century British Fiction (Bloomington, Indianapolis: Indiana University Press, 1998), 10.

103 Dennis Denisoff, Decadent Works and Occult Works by Arthur Machen (Cambridge: The Modern Humanities Research Association, 2018), 38.

104 Green marked homosexuality and was also Wilde's favourite colour. He used the colour in his texts and connected it with decadence. For example, in his essay Pen, Pencil, and Poison (1891) he wrote, "the curious love of green, which in individuals is always the sign of subtle, artistic temperament, and in nations is said to denote a laxity, if not a decadence, of morals". David Weir, Decadent Culture in the United States: Art and Literature against the American Grain, 1890-1926 (New York: State University of New York Press, 2008), 69.

105 For example, one can find shades of green next to predominant yellow in František Kupka self-portrait The Yellow Scale (1907), which is the cover image of Huysman's decadent novel Against Nature, published in 2003.

106 Estonian artist Endel Kõks uses only yellow and black to visualise melancholia in his painting In the Café II (Kohvikus, 1940, Estonian Art Museum). Other good examples are Georges Lacombe's Yellow Sea (La mer Jaune, 1892, Musée des Beaux Arts, Brest) and Otto Dix, Melancholy (Melancholie, 1930, Kunstmuseum Stuttgart).

107 Gage, Colour and Meaning: Art, Science and Symbolism, 57, 73. The most famous combiner of blue and yellow is Vincent van Gogh, but the same colour combination has been used to imply melancholic mood by some Estonian artists: Johannes Greenberg in the painting Sadness (Kurbus, 1940-1944, Estonian Art Museum) and Oskar Kallis in the painting Fever (Palavik, 1917, Estonian Art Museum) and Under the Summer Sun (Suvipäikese paistel, 1917, Estonian Art Museum). 
thorough study of the psychological effect of colours. In Goethe's theory, colours are positioned between darkness (blue) and light (yellow), and their different affects on a person's emotions provides them with different moral values. According to Goethe, blue is one of the most fascinating colours, but as it is associable with darkness, it is also sombre, melancholic and cold. Warm and light yellow as the opposite of blue is the colour of joy, but when it is dull or mixed and greenish, it can seem repulsive. ${ }^{108}$ So it is not just the visual contrast between blue and yellow that matters, but also the symbolic meaning. Blue, the most famous symbolic colour of melancholia, has had that connotation at least since the Middle Ages. ${ }^{109}$ The best-known example in art is Pablo Picasso's Blue Period, in which greyish-black shades dominate next to blue. ${ }^{110}$

Blue plays a particularly meaningful role in Wiiralt's watercolour Painter (Fig. 9), in which the colour that signifies melancholia is used to highlight objects that symbolise the same condition. The picture depicts a dignified artist sitting in front of a canvas, but not painting. The dark blue spectacles on his nose do not allow him to paint, but there is in fact no need for sunglasses because the sky is covered by cloud. The tired-looking artists seems to be suffering from a creative crisis, which is hinted at by his slanting posture and tired look directed at the empty canvas in front of him. His low spirits is also symbolised by the pile of cold stones on which he sits. Being highlighted with blue, they stand out next to the white empty canvas, which catches the viewer's eye as a contrast to the intense blue. Wiiralt used the same technique in his Melancholy (Fig. 7), in which the scenic view behind the melancholic woman is painted in light blue.

Another dominant colour in Painter is yellow, which might be symbolic of the psychological condition because it has been applied to highlight the clouds, which signify low spirits, and the (evening) sky. Yellow is obviously there to fulfil a compositional task, i.e. to serve as a contrast to the blue and create emotional tension. Studying

108 Johann Wolfgang Goethe, Theory of Colours (London: John Murray, 1840 [1810]), 308, 311. Colour theorists and artists, who take into account the effect of colours on emotions, are usually in dialogue (even indirectly) with Goethe's colour theory.

109 Michel Pastoureau, Sinine: ühe värvi ajalugu (Tallinn: Varrak, 2013 [2002]), 119.

110 Estonian artist Hugo Lepik used the colour combination to imply sadness in his work Portrait of a Man (Mehe portree, 1933, Estonian Art Museum). Gori used the same colour combination in his picture of blasé looking urbanites, titled Sphinx (Sfinks, 1910s, Under and Tuglas Literature Centre, Tallinn). 
Wiiralt's art and his use of colour I have noticed the influence of Vincent van Gogh, who also loved the blue-yellow contrast. ${ }^{111}$ Hence, in Painter the colours yellow and blue bring to the fore the elements of nature and the artist, and signify, with the objects they highlight, a melancholic and neurasthenic condition. By the looks of his outfit the artist seems to be a city gentleman who has arrived in the country to rest his nerves and restore his creativity. ${ }^{112}$ The field and buildings in the picture refer to the countryside.

The dispirited urbanite and autumnal colours appear in an interesting combination in Natalie Mei's drawing Vivo, aut non vivo? (1918, Fig. 11). Mei depicts a suicidal human figure with a sullen look leaning against a wall. The title is a mixture of Latin and Italian and could be translated as To Be or Not to Be? Mei the artist is known for being ironic about widely uttered misogynistic ideas, at the same time attempting to interpret the favourite topics and concepts of decadence in relation to these ideas in a new way. ${ }^{113}$ The picture in question is unique in the sense that the colour references to autumn are made by depicting indoor, rather than outdoor, scenes. The walls, floor and ceiling in the picture have been painted in autumnal shades - Mei combined yellow with ochre and purple. The yellow light shining down on the suicidal character places him at the centre of our attention as though he is on stage. It may be presumed that yellow in this case marks melancholia but also mental illness or madness, because from the medical point of view suicide was categorised as mental illness, and according to Wassily Kandinsky's colour theory yellow was associated with madness - an interpretation that can also be found in Estonian literature. ${ }^{114}$

111 In addition to Gogh-like colour use, Wiiralt also has two self-portraits with emphasis on the ear - just compare Wiiralt's Self-Portrait (Autoportree, 1919 and ca. 1920, Estonian Art Museum) with van Gogh's Self-Portrait with Bandaged Ear and Pipe (Autoportrait avec oreille et tuyau bandes, 1889, private collection; 1899, Courtauld Institute Galleries, London) and SelfPortrait (Autoportrait, 1887, The Detroit Institute of Arts).

112 This idea about exhausting urban life and invigorating or relaxing effect of nature manifests in Estonian decadent literature, too. Mirjam Hinrikus, Dekadentlik modernsuskogemus A. H. Tammsaare ja nooreestlaste loomingus, 41, 45-46, 61.

113 Kai Stahl, "Kultuuriruum ja Natalie Mei prostitutsiooniteemalised joonistused", Kunstiteaduslikke uurimusi, 1-2 (20) (2011), 135-154; Kass, "Teemad ja kujundid ning baudelaire'lik tundeilm", 110-111.

114 For example, in August Gailit's decadent writings Yellow Madness (Kollane hullumeelsus, 1919) and Phosphorus Disease (Fosfortõbi, 1919). 
FIG. 11. NATALIE MEI, VIVO, AUT NON VIVO?, INDIAN INK, WATERCOLOUR ON PAPER (1918). $14.8 \times 12.8$ CM. ART MUSEUM OF ESTONIA. PHOTO: STANISLAV STEPAŠKO.

Black is also significant in addition to the yellow, or to be more specific, the black window placed at the same level as the black jacket of the self-murderer, which helps highlight them both. That black window calls to mind the well-known poem by Juhan Liiv: "Our room has a black ceiling, /---/ The things it has heard and seen 
/---/ Seen lots of tears, crying and lots of fighting, too, so much, so much pain /---/."115 Liiv was considered a tortured genius whose pessimistic oeuvre as well as his personality disorders have been the subject of broader discussion. ${ }^{116}$ But the similarity of the two works lies in the fact that both authors symbolise and emphasise melancholia through the only black element in the room, unless we also take into account the black elements on the male figure in Vivo, aut non vivo? On a metaphorical level the window sees the whole room (including the self-murderer), as does the black ceiling in the poem. The similarity of the text and picture may not even be coincidental, because Mei graduated from Pallas Art School with illustrations to Liiv's story Shadow (Vari, 1894). ${ }^{117}$ Thus, Mei uses colour to refer to autumn as the symbol of melancholia, and then uses single colour accents of yellow and black to emphasise that condition. But besides colour symbolism, the modern design and emptiness of the room is meaningful because it hints at the connection between mental health problems and city life - judging from the outfit and haircut, the depicted figure is an urbanite. The room also creates associations with the sense of emptiness experienced by someone suffering from melancholia: on the one hand there is the feeling of heaviness in the entire body and on the other an empty or hollow feeling in the chest.

115 Juhan Liiv, "Must lagi on meie toal”, Juhan Liivi luuletused (Tartu: Noor-Eesti, 1909), 35.

116 Liiv's image is greatly based on the public presentations and writings of Luiga, who was his doctor, and writer Friedebert Tuglas. The latter was influenced by Liiv and emphasised Liiv's mental issues in his monograph on Liiv, published in 1914 and 1927. E. Kirjand S., "Kõnekoosolek Tallinnas", Tallinna Teataja, 07.12.1913; Luiga, "Juhan Liiv. Mälestused ja märkused I", 505518; Articles in the publication Friedebrt Tuglas. Kogutud teosed, 12, ed. by Elle-Mari Talivee (Tallinn: Underi ja Tuglase Kirjanduskeskus, 2013): Jüri Talvet, "Tuglase Liiv ehk meelehaige luuleilme”, 395, 401-404; Jaan Undusk, "Tuglase sümbolistlik manifest”, 472.

117 There is no information about whether Mei was familiar with Liiv's poetry, although it is known that she read the story Shadow in her childhood. In 1918, she started her studies under the guidance of Triik, who knew Liiv; Triik made a portrait of him, which was used as an illustration in Tuglas's book on Liiv (Juhan Liiv: monograafia, 1914). Kai Stahl, Ainulaadne sõsarkond. Õed Kristine, Lydia ja Natalie Mei (Tallinn: Eesti Kunstimuuseum, 2020), 111, 131. Mei was also very keen on the field of literary and made illustrations for various publications as well as working as a costume designer at the Estonia Theatre. Ibidem, 11, 116-122, 157-168. Kai Stahl has asserted that Vivo, aut non vivo? bears a resemblance to the style of Beardsely and Mir Iskusstva, whose works Mei was probably familiar with. Ibidem, 112. 


\section{CONCLUSION}

In the early $20^{\text {th }}$ century, increasing attention was paid in Estonia to moods and mental health issues. This interest was brought about by developments in medicine, discussions about breed and the surfacing ideas of eugenics and the study of heredity. At the same time, degeneration theories began to gain ground, according to which contemporary civilisation was bound to degrade, and an increase in mental problems was seen as a sign of that degradation in addition to various social and cultural processes. These issues became topical when doctors and press started to claim that Estonians frequently suffered from weak nerves/neurasthenia and from (accompanying) melancholia or even suicidal behaviour. There were discussions about whether to regard biological factors as their cause, or social processes that caused stress and trauma, leading to mental illnesses including deep melancholia. The main reason for these social factors was believed to be modernisation, urbanisation in particular, which brought about an unusually intense and therefore exhausting way of life. The city was regarded as a frantic and tiresome place and urban society as a source of stress.

Discussions about the psyche and illnesses, as well as about the social processes that were interpreted as negative, influenced visual arts in Estonia. Art began to demonstrate an increasing interest in emotions and the psyche. Estonian decadent art at the beginning of the $20^{\text {th }}$ century started to focus on depicting low spirits and developed some widely used techniques to express that. These techniques are not unique to Estonian art, they are characteristic of decadent art and literature across Europe. Meaning, in addition to the above mentioned discussions about mental health issues, the foreign and local decadent works had a great effect on the increasing interest in melancholia. We can thus speak about intertextuality in visualising melancholia in art: certain viewpoints on melancholia spread through intertexts such as social processes, art and literary works, and bring with them related techniques such as symbols that generate similar associations.

Body language became a central means of visualising melancholia. The traditional melancholia pose, a tilted head supported by one hand and a slack posture lacking energy and symbolising despondency and sadness, was frequently applied. The traditional melancholia 
pose had previously been used in art for centuries, but in decadence certain elements of the head (for example the gaze) and its posture became the focal point, because an expressive head can convey a mood. But the tilted head slanting towards the ground probably also symbolised harrowing and restless thoughts as a symptom of melancholia. At least different texts suggest this. Images like skeletons and skulls were also used to create allusions to the tragic outcomes of melancholia, to the possibility that this condition could destroy a human being and give rise to suicidal thoughts. Melancholia was not only conveyed through various elements in the picture, which functioned as signs with their intertextual or established meanings, but also through composition. For example, various natural images were used as symbols of a melancholic mood. Stones with their heaviness and coldness became widespread symbols, while expressions like 'heavy feeling' or 'weighed down' are part of the vocabulary used to describe the condition, referring to a feeling of heaviness in one's body or head. The rock was usually placed at the centre of the composition or somewhere in the close vicinity of the melancholic figure to emphasise the gloomy state. Cloudy or evening skies were also often used in contrast to sunny moments associated with joy. Such an atmosphere created allusions to autumn, which was associated with melancholia. Thus, autumn was a widespread motif in depicting melancholia. It is noteworthy that autumn was referred to not only through natural imagery but also through colour. This was often used to symbolise mood, and in doing so artists were influenced by perceptions that were currently fashionable as well as by those that had been established over the centuries, i.e. meanings attached to colours. Autumnal colours, particularly yellow, were widely used, with different negative meanings at different times. At the turn of the $20^{\text {th }}$ century it came to symbolise illness, decay and decadence. Melancholia was also depicted with shades of grey and black, associated with joylessness, heaviness and monotony. Blue was another popular colour that was used to symbolise melancholia at least since the Middle Ages. Melancholia was hence visualised metaphorically. Different widespread images and techniques were intertwined to express it and were regarded as relating to low spirits. 
Lola Annabel Kass: Picturing Melancholia in Estonian Decadent Art

KeyWords: DeCADENT ART; MELANChOly; MELANCHOLIA; COLOUR SYMBOLISM; NATURE SYMBOLISM

\section{SUMMARY}

The article focuses on Estonian decadent art of the early twentieth century that manifests the topicality of melancholia: visual art that depicts sadness, low spirits, malaise and suicidal behaviour. The article seeks to answer why portrayal of the feeling of malaise and low spirits were so widespread from the beginning of the $20^{\text {th }}$ century, and how Estonian artists imagined and visualised melancholia.

I argue, that during the period under examination, increasing attention was paid in Estonia to mental health issues, including melancholia, which was brought about by discussions about breed and the surfacing ideas of eugenics and the study of heredity. These were connected to the degeneration theories, according to which contemporary civilisation was bound to degrade, and an increase in mental problems was seen as a sign of that degradation in addition to various social and cultural processes. In addition, Estonian artists were influenced (directly or indirectly) by foreign artworks, literature and poetry that deal with the tragical and horrific side of humanity, such as mental health issues. I examine how artist depicted melancholia: in a symbolic manner mainly through body language and body parts, but that the condition was also conveyed through the use of natural imagery and colour.

\section{CV}

Lola Annabel Kass is a doctoral student and an early-stage researcher in art history at the School of Humanities, Tallinn University. Kass' research interests are early-20 $20^{\text {th }}$-century Estonian art, decadent art and the relationship between the visual arts and literature. In addition to her academic work she has curated exhibitions, including Children of the Flowers of Evil: Estonian Decadent Art, the first exhibition exploring Estonian decadent art, at Kumu Art Museum in Tallinn (2017-2018). 